\title{
Central African Republic: Request for a Three-Year Arrangement Under the Poverty Reduction and Growth Facility-Staff Report; Staff Statement; Press Release on the Executive Board Discussion; and Statement by the Executive Director for the Central African Republic
}

In the context of the request for a three-year arrangement under the Poverty Reduction and Growth Facility, the following documents have been released and are included in this package:

- $\quad$ the staff report for the request for a three-year arrangement under the Poverty Reduction and Growth Facility, prepared by a staff team of the IMF, following discussions that ended on November 11, 2006, with the officials of the Central African Republic on economic developments and policies. Based on information available at the time of these discussions, the staff report was completed on December 7, 2006. The views expressed in the staff report are those of the staff team and do not necessarily reflect the views of the Executive Board of the IMF;

- $\quad$ a staff statement of December 22, 2006 updating information on recent developments;

- $\quad$ a Press Release summarizing the views of the Executive Board as expressed during its December 22, 2006 discussion of the staff report that completed the request; and

- $\quad$ a statement by the Executive Director for the Central African Republic.

The documents listed below have been or will be separately released.

Letter of Intent sent to the IMF by the authorities of the Central African Republic* Memorandum of Economic and Financial Policies by the authorities of the Central African Republic* Technical Memorandum of Understanding*

*Also included in Staff Report

The policy of publication of staff reports and other documents allows for the deletion of market-sensitive information.

To assist the IMF in evaluating the publication policy, reader comments are invited and may be sent by e-mail to publicationpolicy@imf.org.

Copies of this report are available to the public from

International Monetary Fund • Publication Services

$70019^{\text {th }}$ Street, N.W. • Washington, D.C. 20431

Telephone: (202) 623-7430 • Telefax: (202) 623-7201

E-mail: publications@imf.org • Internet: http://www.imf.org

Price: $\$ 18.00$ a copy

\section{International Monetary Fund Washington, D.C.}





\title{
INTERNATIONAL MONETARY FUND
}

\section{CENTRAL AFRICAN REPUBLIC}

\section{Request for a Three-Year Arrangement Under the Poverty Reduction and Growth Facility}

\author{
Prepared by the African Department \\ (In consultation with other departments) \\ Approved by Saul Lizondo and Mark Plant
}

December 7, 2006

- A staff team visited Bangui November 4-11, 2006 to discuss a medium-term economic and financial framework that could be supported by a three-year Poverty Reduction and Growth Facility (PRGF) arrangement. The staff met with President Bozizé, Prime Minister and Minister of Finance Elie Doté, other government officials (including from the regional central bank), Speaker of the National Assembly Gaombalet and other members of parliament, and representatives of the private sector, labor unions, donors, and the media. The staff team consisted of Mr. York (head), Mr. Bakhache, Mr. Nachega, and Ms. Schumacher (all AFR), and Mr. Detchou (BLS). Mr. Tall (OED) also participated in the discussions.

- The Executive Board approved a first purchase in July 2004 of SDR 5.57 million (10 percent of quota) under the Emergency Post-Conflict Assistance (EPCA) policy and a second purchase in January 2006 of SDR 6.96 million (12.5 percent of quota). The EPCA was designed to support the authorities' early efforts to reform the economy after the civil war ended and to act as a catalyst for wider donor support. It was envisaged that satisfactory performance under the recent EPCA would lead to a PRGF arrangement.

- The Central African Republic is a member of the Central African Economic and Monetary Community (CEMAC) and its regional central bank (BEAC). The common currency, the CFA franc, is pegged to the euro at CFAF 656.

- In the Letter of Intent and Memorandum of Economic and Financial Policies accompanying this staff report, the C.A.R. authorities are requesting a three-year PRGF arrangement for 2007-09. Proposed access under the arrangement is set at SDR 36.20 million (65 percent of quota). The first disbursement of SDR 17.6 million, which would be available upon Executive Board approval of the arrangement, is set high to allow the authorities to refinance the outstanding EPCA loans with PRGF resources to extend the repayment profile, thus increasing concessionality, and to keep sufficient resources in their SDR Account to meet PRGF obligations that come due through the third quarter of 2007. At that time, the authorities hope to reach the decision point under the enhanced Heavily Indebted Poor Countries (HIPC) Initiative.

- The authorities have consented to the publication of this staff report, the Letter of Intent, and the Memorandum of Economic and Financial Policies on the Fund website. The C.A.R.'s relations with the Fund and the World Bank, and statistical issues are detailed in the attached appendices. 
Executive Summary

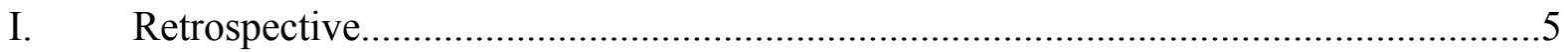

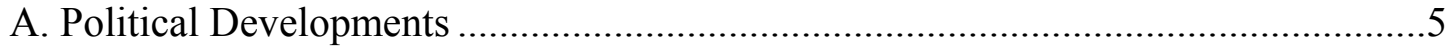

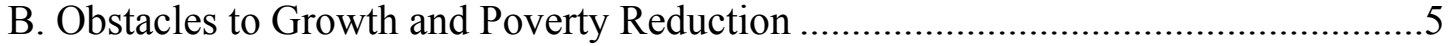

C. Reengagement with the International Community ...........................................6

II. Recent Developments and Performance ............................................................... 7

III. The Foundations For Growth and Poverty Reduction ......................................... 9

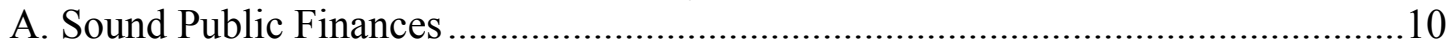

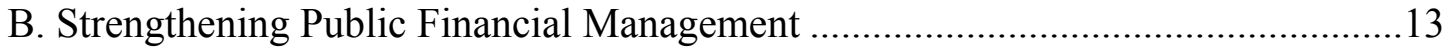

C. Reviving the Private Sector............................................................................. 13

D. Capacity Building ................................................................................... 14

E. The Poverty Reduction Strategy Paper............................................................15

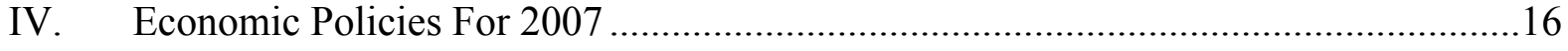

V. Program Financing and Capacity to Repay the Fund ..........................................17

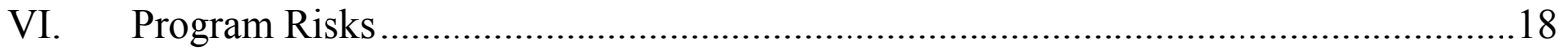

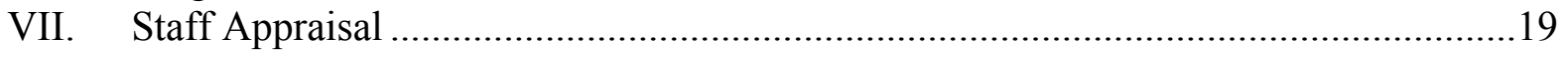

Boxes

1. Debt Sustainability Analysis........................................................................ 11

2. Structural Policies: Areas of Development Partners Involvement, 2006-07.............15

Tables

1. Selected Economic and Financial Indicators, 2004-09 ......................................25

2. Authorities' Indicative Targets, March 1-December 31, 2006................................26

3. Central Government Operations, 2004-09 (in billions of CFA francs, unless

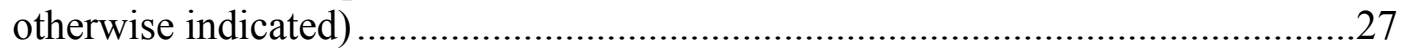

4. Central Government Operations, 2004-09 (in percent of GDP) ..............................28

5. Structural Measures Under the 2006 EPCA Program................................................29

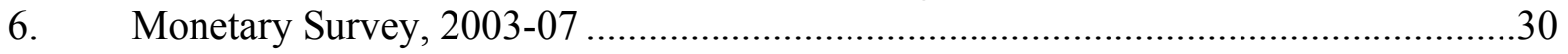

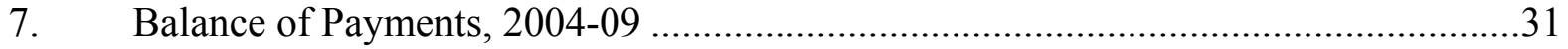

8. Proposed Access and Phasing Under the Three-Year PRGF Arrangement ...............32

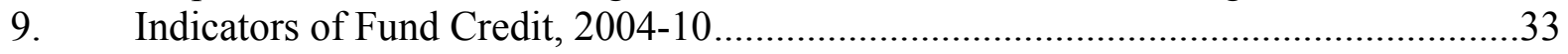

10. Millennium Development Goals, 1990-2004 ....................................................34

11. External Debt Sustainability Framework, Baseline Scenario, 2002-25 ....................36

12. Sensitivity Analyses for Key Indicators of Public and Publicly Guaranteed External Debt, 2005-25 
Appendices

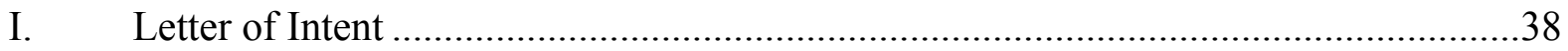

Attachment I: Memorandum of Economic and Financial Policies, 2007-09..........39

Table 1. Quantitative Performance Criteria and Benchmarks Under the PRGF Arrangement, 2007 ..........................................................51

Table 2. Prior Action, Structural Performance Criteria and Benchmarks Under the PRGF Arrangement, 2007...........................................52

Attachment II: Technical Memorandum of Understanding.................................53

Table 1. Data Provision to the IMF Under the PRGF Arrangement .................57

Table 2. Foreign Grants and Budget Support, 2007 .....................................58

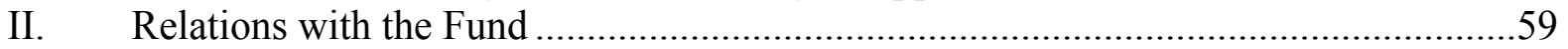

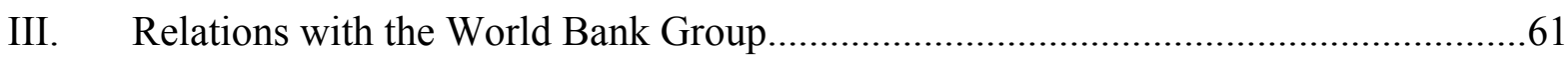

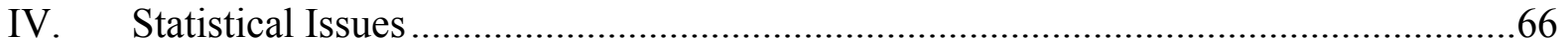




\section{EXECUTIVE SUMMARY}

The political and social situation has been generally stable. However, tensions remain, partly because the economic recovery has been modest and the financial situation is difficult. There is instability and some actual conflict in the northern border area with Chad and Sudan but the authorities have expressed confidence that economic reform and program implementation would not be adversely affected by these developments.

\section{Recent developments}

- The economic recovery since the political transition from the March 2003 coup d'état has been modest. However, economic activity has picked up recently and real GDP growth is expected to reach about $3 \frac{1}{2}$ percent this year. Twelve-month inflation is currently about 5 percent but is on a declining trend.

- Performance under the authorities' Emergency Post-Conflict Assistance (EPCA) program has been generally satisfactory through end-September 2006, taking account of the difficult external environment (high oil prices, instability in the north of the country, a low level of official inflows). Overall, the main objectives of the EPCA program for this year should be achieved, with a moderate increase in economic growth, an improved fiscal position, and some progress in structural policies. In recognition of recent progress, the international community has been increasing support to the country. In particular, arrears to the World Bank have now been cleared and those to the African Development Bank are expected to be cleared ahead of the Executive Board discussion; and the Paris Club has provided financing assurances to Fund staff in support of the proposed PRGF arrangement. Also, the government is making good faith efforts to reach a collaborative agreement with its other bilateral and commercial creditors.

\section{Economic policies in the period ahead}

- The authorities' program for 2007-09 aims to build a firm foundation for accelerating private sector-led growth and alleviating poverty. In this regard, the main objectives are to achieve real GDP growth of 4-5 percent per annum to allow for modest progress toward reaching the Millennium Development Goals; further fiscal consolidation to gradually eliminate the overhang of domestic debt and open room to support growth-enhancing and poverty-reducing social policies; increase credit to the private sector; and make external debt sustainable by regularizing relations with external creditors and benefiting from debt relief under the enhanced Heavily Indebted Poor Countries and Multilateral Debt Relief Initiatives.

- During the first year of the program, the macroeconomic framework targets real GDP growth of 4 percent and a reduction of inflation to about 3 percent. The policies to achieve these objectives include a 2007 budget that targets a domestic primary surplus of about 1 percent of GDP; measures to strengthen public financial management and stabilize the financial sector; and regulatory reforms that will enhance governance and improve the investment climate in the natural resource sector.

Given the strength of the authorities' program, including the prior action to be taken, the staff supports their request for a three-year PRGF arrangement in an amount equivalent to SDR 36.20 million (65 percent of quota). 


\section{RETROSPECTIVE}

\section{A. Political Developments}

1. François Bozizé was elected President of the Central African Republic (C.A.R.) in May 2005 at the end of the political transition from the March 2003 coup d'état. The presidential and parliamentary elections were considered free and fair and the political situation has been generally peaceful since. However, tensions remain, partly because the economic recovery has been modest and the financial situation is difficult. The banditry that persists in the rural areas is particularly problematic for the agriculture sector but also affects transportation through the economic corridor with Cameroon. There is instability and some actual conflict in the border areas with Chad and Sudan in the north. The authorities have expressed confidence that economic reform and program implementation would not be adversely affected by these developments.

\section{B. Obstacles to Growth and Poverty Reduction}

2. The economic situation in the C.A.R. has deteriorated markedly in the last two decades. Real domestic per capita income has plummeted since the late 1980s, owing to political and social instability, economic mismanagement, and a worsening of the terms of trade. Fortunately, this trend is subsiding as political and social conditions become more stable and the authorities turn their attention to economic management. Not surprisingly, there has been virtually no progress-and perhaps some setbacks-towards achieving the Millennium Development Goals (MDGs).

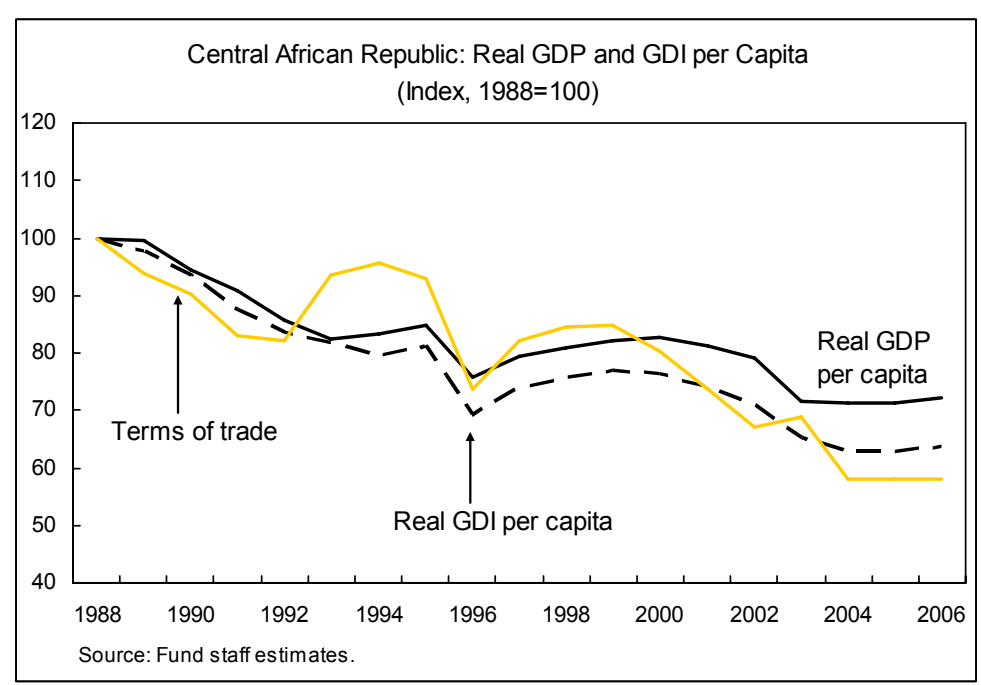

3. The C.A.R. must deal with major obstacles to growth and poverty reduction:

- The country is landlocked and import-dependent, and the agriculture-based economy has a narrow export base which makes it vulnerable to adverse changes in the terms of trade.

- The cost of doing business is high because physical and human capital deteriorated during the long period of conflict and disinvestment. The lack of adequate transportation and its high cost are major impediments to building a competitive export sector.

- The fiscal position is weak: the tax-revenue ratio is among the lowest in developing countries, public expenditures fall short of the country's vast social and public 
investment needs, and the government has accumulated a large domestic debt, part of which is payments arrears.

- Financial intermediation and access to financial services are minimal. Total bank credit to the private sector is equivalent to less than 7 percent of GDP.

- The external debt burden is unsustainable. The estimated net present value of external debt-to-exports ratio was above 500 percent at the end of 2005.

- Weak governance and institutional and administrative capacity limits government ability to formulate, implement, and evaluate economic policy. This also provides an avenue for corruption that undermines the effective use of public resources, resource mobilization, and drives economic activity into the informal sector.

- $\quad$ Finally, the C.A.R.'s suspension of all external debt service payments in 2001 led to a period of low and intermittent support from the international community.

\section{Reengagement with the International Community}

4. As the political situation and C.A.R.'s economic policies have been improving, the international community is showing increasing interest in reengaging with and increasing support for the

country. The World Bank has now cleared the C.A.R.'s arrears to it and an operation to clear the country's arrears to the African Development Bank (AfDB) is expected ahead of the Executive Board discussion of the authorities' request for a new arrangement; ${ }^{1}$ some of the other multilateral creditors have recently rescheduled the C.A.R.'s

\begin{tabular}{|c|c|c|c|c|}
\hline & \multicolumn{2}{|c|}{ Nominal Debt Stock } & \multicolumn{2}{|c|}{ Arrears Stock } \\
\hline & US\$ million & $\begin{array}{c}\text { Percent } \\
\text { of total }\end{array}$ & US\$ million & $\begin{array}{c}\text { Percent } \\
\text { of total }\end{array}$ \\
\hline Total & 967.3 & 100.0 & 328.2 & 100.0 \\
\hline Multilateral & 603.9 & 62.4 & 102.2 & 31.1 \\
\hline World Bank & 388.9 & 40.2 & 49.1 & 15.0 \\
\hline IMF & 35.9 & 3.7 & 0.0 & 0.0 \\
\hline AfDB Group & 123.2 & 12.7 & 36.1 & 11.0 \\
\hline IFAD & 26.7 & 2.8 & 6.8 & 2.1 \\
\hline European Investment Bank & 6.3 & 0.6 & 0.5 & 0.2 \\
\hline BDEAC & 11.0 & 1.1 & 0.3 & 0.1 \\
\hline BADEA & 12.0 & 1.2 & 0.0 & 0.0 \\
\hline OPEC & 0.0 & 0.0 & 9.4 & 2.9 \\
\hline Bilateral and Commercial & 363.4 & 37.6 & 226.0 & 68.9 \\
\hline Bilateral & 315.0 & 32.6 & 184.3 & 56.1 \\
\hline Paris Club & 69.1 & 7.1 & 23.2 & 7.1 \\
\hline Other Official Bilateral & 245.8 & 25.4 & 161.0 & 49.1 \\
\hline Commercial & 48.4 & 5.0 & 41.8 & 12.7 \\
\hline
\end{tabular}
debt, resulting in a positive resource transfer flow over the program period; and the donor base has been widened.

5. Since 2004, when the C.A.R. began to pay debt service to the Fund, there has been gradual but steady Fund reengagement. The Executive Board approved a first Emergency Post-Conflict Assistance (EPCA) program in July 2004 with a disbursement of

\footnotetext{
${ }^{1}$ The World Bank's operation involved clearing arrears, providing resources to service debt through September 2007, and budget support. The AfDB's operation involves clearing arrears and providing resources to service debt through 2007.
} 
10 percent of quota and a second in January 2006 with a disbursement of 12.5 percent of quota. The EPCA disbursements were designed to support the authorities' early efforts to reform the economy after the civil war ended and to act as a catalyst for wider donor support. Also, the Fund has helped build institutional and administrative capacity through assistance in public financial management and statistics.

6. Fund support to the C.A.R. under a PRGF arrangement would be an integral part of an international community's coordinated effort to bolster support to the country. It would help to sustain improved economic policies and facilitate the clearance of external arrears and efforts to regularize relations with external creditors. While improving the country's economic prospects will require strong internal program ownership and economic management, financial and technical support from the international community will also be essential because domestic resources will be comparatively small even with stepped-up efforts to mobilize revenue.

\section{Recent Developments And Performance}

7. Economic performance has been improving, to a large extent attributable to better economic management. The implementation of the EPCA-supported program has generally been satisfactory, taking account of the difficult external environment-in particular, instability in the north of the country, high world oil prices, and a low level of foreign assistance. Overall, the objectives of the authorities' program for this year should be achieved, with a moderate increase in economic growth, an improved fiscal position, and some progress in structural reform.

8. Economic activity began to recover in 2004 and real GDP growth is projected to rise to about $3 \frac{1}{2}$ percent this year (Table 1). The pickup mainly reflects improvements in the mining and forestry sectors, but also more activity in the secondary and tertiary sectors. The 12-month rate of inflation was about 5 percent in September, partly due to an adjustment of petroleum product prices and an increase in indirect taxes, but is on a declining trend.

9. The current account deficit is projected to widen moderately this year, to 3.3 percent of GDP. This mainly reflects lower official transfers. The impact of higher world oil prices on the trade balance will be broadly offset by higher prices for C.A.R. commodity exports. The real effective exchange rate appreciated by about 6 percent in the first half of 2006, mainly because of relatively high inflation in the C.A.R.

10. The fiscal position is projected to improve noticeably this year. Revenue is expected to increase, while expenditure would fall markedly as a result of measures to reduce the wage bill, a retrenchment from last year's election-related spending, and a decline in foreign-financed investment (due in part to the completion of some projects). Consequently, the domestic primary balance is projected to move from a deficit of $3 \frac{1}{2}$ percent of GDP in 2005 to a primary surplus of about $1 / 2$ percent of GDP in 2006. 


\section{Compared with the EPCA-supported program, revenue is expected to perform} better than anticipated. This is because of stronger growth and measures to enhance tax administration (increasing compliance and collections, and more effective audits). Through September, tax revenue exceeded the authorities' target by 0.2 percent of GDP (Table 2). Performance is expected to remain strong through the rest of the year, and the tax revenue ratio should reach its highest level in a number of years.

\section{Domestic non-interest spending, on the other hand, was above the target by} about 0.4 percent of GDP through September, and the slippage is likely to increase slightly in the fourth quarter. The overspending is attributable to a subsidy ( 0.2 percent of GDP) to jump-start the cotton sector, which the government deems imperative to enhance growth and alleviate poverty in rural areas, unanticipated defense spending related to the conflict in the north, and increased petroleum-related subsidies to offset higher world oil prices. Wages and salaries were slightly above budget through September because of outlays (tied to a French grant) to support early retirements, and salary payments to 720 civil servants (including military personnel) who had been inadvertently left off the payroll census earlier this year. On the positive side, there were payments on domestic arrears including for wages and salaries, goods and services, and pensions from 2005, equivalent to 0.5 percent of GDP. ${ }^{2}$

\section{The improvement in the fiscal situation has been supported by enhanced}

financial management. Reforms in tax administration, such as the audit and control of large taxpayers, and efforts to strengthen taxpayer compliance have improved tax collection. The control and monitoring of public expenditures have been enhanced with the help of FAD technical assistance, by closing a significant number of government commercial bank accounts (100 during this year), using the payroll census to eliminate fraud and duplication in the civil service, and limiting the issuance of treasury checks which have been a major source of slippage. The recent adoption of a new budget classification system and budget law should further enhance public financial management.

\section{Net credit to the government from the banking system was slightly higher than} planned in the first eight months of the year. The government resorted to some commercial borrowing to alleviate a short-term liquidity constraint, but these liabilities are expected to be repaid by the end of the year. The liquidity constraint should ease somewhat because the C.A.R.'s CEMAC partners agreed recently to reschedule the country's debt to the regional central bank (BEAC) on concessional terms. ${ }^{3}$ Credit to the private sector increased only slightly.

\footnotetext{
${ }^{2}$ There have been some administrative problems that have caused some short delays in paying wages but no new wage arrears have accrued.

${ }^{3}$ C.A.R. debt to the BEAC equivalent to about 7.3 percent of GDP will be restructured to increase the maturity from 3 to 15 years, reduce the interest rate from 10 to 3 percent, and increase the grace period from 6 months to 5 years.
} 


\section{Structural policies have been directed to enhancing governance and improving} the ability of the legal system to address financial and commercial crime. All the structural benchmarks for the EPCA have been implemented, a few with a delay (Table 5). The government has a website on which it posts fiscal data, real sector indicators, and information on progress in combating corruption and impunity. ${ }^{4}$ The State Judicial Agent and the financial unit in charge of prosecuting financial corruption in the Ministry of Justice are operational, although their work is hampered by the lack of staff and equipment. Reform of the judiciary has begun, with assistance from development partners.

\section{The Foundations For Growth ANd Poverty Reduction}

\section{The medium-term program agreed with the authorities aims to build a firm} foundation for accelerating private-sector led growth and alleviating poverty. The program seeks to address the obstacles to growth and the constraints to development so as to achieve annual real GDP growth of 4-5 percent through 2009 to allow for modest but continued progress toward meeting the income and other MDGs. The program also envisages a reduction of annual inflation to below the CEMAC convergence criterion, which should help preserve the country's international competitiveness under the fixed exchange rate regime.

\begin{tabular}{|c|c|c|c|c|}
\hline & 2006 & 2007 & 2008 & 2009 \\
\hline & \multicolumn{4}{|c|}{ (Annual percentage change) } \\
\hline \multicolumn{5}{|l|}{ National income and prices } \\
\hline GDP at constant prices & 3.5 & 4.0 & 4.3 & 4.5 \\
\hline GDP at current prices & 7.5 & 6.5 & 6.9 & 7.1 \\
\hline Consumer prices (yearly average) & 5.1 & 3.1 & 2.3 & 2.4 \\
\hline \multicolumn{5}{|l|}{ External sector } \\
\hline Export volume & 6.1 & 6.2 & 6.1 & 7.0 \\
\hline Import volume & 7.8 & 8.3 & 8.5 & 9.0 \\
\hline \multirow[t]{2}{*}{ Terms of trade (U.S. dollar basis) } & 2.3 & -1.4 & -0.4 & -0.3 \\
\hline & \multicolumn{4}{|c|}{ (In percent of broad money at beginning of period) } \\
\hline \multicolumn{5}{|l|}{ Money and credit } \\
\hline Domestic credit & -8.4 & 1.8 & $\ldots$ & $\ldots$ \\
\hline \multirow[t]{2}{*}{ Broad money } & 4.5 & 7.1 & $\ldots$ & $\ldots$ \\
\hline & \multicolumn{4}{|c|}{ (In percent of GDP) } \\
\hline \multicolumn{5}{|l|}{ Central government finance } \\
\hline Total revenue (including grants) & 12.9 & 15.1 & 14.2 & 14.4 \\
\hline of which: Tax revenue & 7.7 & 8.6 & 9.2 & 9.6 \\
\hline Total expenditure & -12.9 & -13.4 & -13.6 & -13.8 \\
\hline Overall balance (including grants) & 0.0 & 1.7 & 0.6 & 0.6 \\
\hline Domestic primary balance $1 /$ & 0.4 & 1.1 & 1.1 & 1.1 \\
\hline External current account balance & -3.3 & -2.6 & -3.3 & -3.9 \\
\hline Net present value of total debt $2 /$ & 489.3 & 463.8 & 448.5 & 434.3 \\
\hline
\end{tabular}

\footnotetext{
${ }^{4}$ The website is found at http://www.finances-rcagouv.com/.
} 


\section{The medium-term policies to achieve these broad objectives include:}

- Fiscal consolidation to gradually eliminate the overhang of domestic debt, and a reorientation of spending priorities to support growth-enhancing and poverty-reducing social policies. In this regard, strengthening public financial management is a high priority.

- Reforms in the financial sector that will enhance financial intermediation and deepening, and allow for an expansion of credit to the private sector.

- Trade and investment liberalization that will help diversify the economy, expand the export base, and address some of the constraints of being a landlocked and importdependent country. Establishing a level playing field in the natural resource sector is important in this context, since this will be a source of potential export growth.

- $\quad$ Making external debt sustainable by regularizing relations with external creditors and benefiting from debt relief under the enhanced HIPC and Multilateral Debt Relief (MDRI) Initiatives. A debt sustainability analysis confirms that the current situation is unsustainable, even after traditional debt relief mechanisms are applied (Box 1). The external current-account deficit (including grants) is projected to widen to about

4 percent of GDP over the medium term as imports linked to stronger growth and public investment pick up. Annual growth in export volumes is projected to be modest (increasing from a relatively low base), in the 6-7 percent range, because it is constrained by the high cost of doing business and slow progress in rebuilding the country's infrastructure and transportation network. The C.A.R.'s financing needs would continue to be covered by a mix of grants, highly concessional loans, and a projected increase in foreign direct investment.

\section{A. Sound Public Finances}

18. The C.A.R. medium-term fiscal strategy is based on the premise that sound public finances will enhance social stability and bring about improvement in the business climate, after a prolonged period of unproductive spending. The strategy has several elements: fiscal consolidation to reduce the overhang of domestic debt that narrows the room to maneuver; a reorientation of spending priorities; and well-targeted support for vulnerable households and key economic activities, such as cotton production (which is also being supported by development partners). 


\section{Box 1. Debt Sustainability Analysis}

Based on the outstanding external (public- and publicly-guaranteed) debt through 2005, the debt sustainability analysis using the Low-Income Country template (conducted jointly with the World Bank) shows that the C.A.R.'s debt burden is unsustainable, even under the baseline scenario. This scenario includes the prospective arrears clearance to multilateral creditors and a rescheduling of bilateral and commercial debt on Naples terms; also, over the long term real GDP growth averages 4.2 percent (compared with 0.8 percent during 1995-2005) and the current account deficit declines to about 2 percent of GDP (for more details, see Tables 11 and 12). The financing gap is filled by external grants and new borrowing with a 50 percent grant element. The 2005 World Bank's CPIA ranks the C.A.R. as a poor performer, for which the debt-burden thresholds are NPV of debt-to-exports of 100 percent, NPV of debt-to-GDP of 30 percent, and debt service-toexports of 15 percent.

In the baseline scenario, the C.A.R's ratios remain above the indicative thresholds until 2025 except for the debt service ratio, which falls below 15 percent after 2016. In an alternative scenario (with key variables growing at their ten-year historical levels), all ratios stay above the sustainability thresholds, including the debt service ratio. A stress test suggests that the debt situation is highly vulnerable to an export shock.
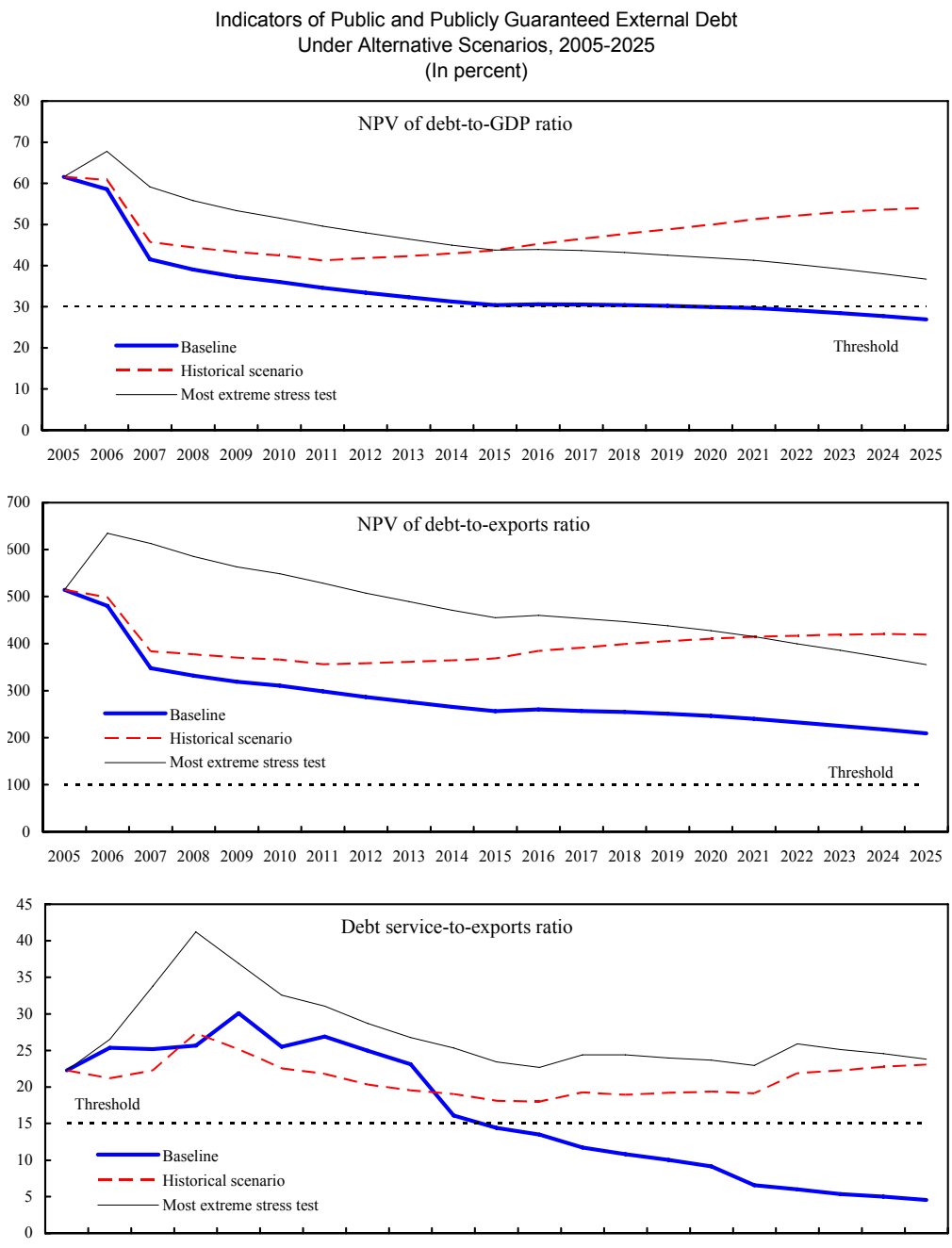

200520062007200820092010201120122013201420152016201720182019202020212022202320242025

Source: IMF staff projections and simulations. 
19. Over the medium term the government will maintain annual domestic primary surpluses equivalent to about 1 percent of GDP. This fiscal stance is sufficient to allow the government to stay current on domestic debt service and start repaying domestic debt (over 21 percent of GDP), which includes liabilities to commercial banks and the BEAC and arrears to other creditors. The plan to repay domestic debt at an annual rate of about $1 \frac{1}{2}-$

2 percent of GDP will help regularize relations with domestic creditors and restore credibility to fiscal policy. Clearance of domestic arrears, especially on wages and pensions, is especially pertinent. These repayments will incorporate the use of domestic resources, foreign assistance, negotiating discounts on some of the amounts due, and even debt-forequity swaps of land and other government assets if such transactions can be arranged.

20. The tax-revenue ratio is envisaged to increase by about 2 percentage points from a relatively low base, to about $9 \frac{1}{2}$ percent of GDP in 2009. This is to be achieved through concerted efforts to reform tax and customs administration, broaden the tax base, and increase taxpayer compliance. Raising tax rates would be less attractive for mobilizing domestic resources because (i) tax rates are already relatively high so further measures would risk driving more activity into the informal sector, leading to further tax evasion and erosion of the tax base; and (ii) experience elsewhere has shown that, post-conflict, administrative reforms are likely to be more successful at least initially than more and higher taxes.

\section{The government will enhance the effectiveness of its limited resources by} rebalancing its spending toward growth-enhancing and poverty-reducing activities. This will require a reduction in less productive outlays, such as foreign travel, government energy consumption, and such administrative costs as telephones. However, it should be noted that a reduction in these outlays will not yield significant savings. This rebalancing will also require tight control over civil service wages and salaries, which has been a persistent source of expenditure slippage and constitutes a disproportionately large share of spending. The government intends to reduce the budgeted wage bill over the medium term and is confident that a reform of the civil service now being designed in consultation with development partners could bring about significant savings. This would then allow for a gradual increase in public investment, especially on infrastructure and spending on health and education. Current outlays in these areas are severely compressed and are well below the levels necessary to reach the MDGs.

\section{The government will also rebalance spending by reforming petroleum-product} pricing and the mechanisms it uses to protect vulnerable households from high world oil prices. Subsidies are currently implicit, consisting of ad hoc tax adjustments to maintain fixed retail prices for petroleum products. The result is an erosion of the tax base, which the government can ill afford. It is also ineffective in providing support to the poor. The government is now working on measures to target subsidies more effectively. Technical assistance from the Fund is expected to guide these reforms. 


\section{B. Strengthening Public Financial Management}

\section{The public financial management system will be strengthened to prevent the} recurrence of expenditure slippages. This is also crucial to the fight against corruption and enhancing governance of public resources. With the benefit of technical assistance, the authorities aim to (i) tighten spending controls; (ii) enhance budget formulation and reinforce the expenditure process; (iii) address the sources of past expenditure slippages (such as extrabudgetary spending, cash advances, and the use of Treasury checks not backed by cash); (iv) improve the monitoring, reporting and performance of all revenue sources; (v) ensure the transparency of all state transactions, within and outside the government; and (vi) formulate a strategy for more transparently transferring resources to and from the provinces. The Fund has a long-term resident public financial management advisor to assist with reforms in several of these areas.

\section{Reviving the Private Sector}

24. Structural reform is necessary to restore private sector confidence in economic policies, which is vital if there is to be a sustained recovery. Over the medium term, the authorities will work to enhance financial stability and development, open the economy to trade and investment, and ensure equitable treatment in the natural resource sector.

\section{The authorities will build on the benefits of membership in the CEMAC and the strength of its financial institutions by pursuing a national strategy that promotes reforms to facilitate access to credit and remove obstacles to financial intermediation.} The strategy is guided by the recent regional Financial Sector Stability Assessment and will be further refined by the forthcoming country module, expected early next year. It has two prongs:

- To stabilize the financial sector by (i) strengthening commercial banks' balance sheets by addressing the non-performing loans on those balance sheets, attributed to past borrowing from state-owned enterprises ${ }^{5}$; and (ii) to facilitate the recapitalization of a troubled bank, without contributing additional government resources. In this regard, the government's intention to recognize the state-owned enterprises' non-performing loans will facilitate a resolution to this problem bank $^{6}$; and

\footnotetext{
${ }^{5}$ One option being considered is for the government to replace these non-performing loans by new government bonds (bank-restructuring bonds). However, before deciding on the options to take, the government must verify the outstanding stock of state-owned enterprises' non-performing loans.

${ }^{6}$ The problem bank has significant state-owned enterprises' non-performing loans on its balance sheet and prospective investors have been reluctant to move, given the uncertainty over the status and treatment of these loans.
} 
- To introduce reforms of the regulatory and legal framework, to strengthen governance, and reduce lending risks thus increasing the supply of credit.

26. The authorities will seek further trade liberalization to overcome the small size of the market and the relatively high costs to both consumers and producers. C.A.R. is prepared to work with its CEMAC partners to lower the common external tariff and to reduce other barriers to intraregional trade. The authorities expect the program to benefit from the Diagnostic Trade Integration Study and the World Trade Organization's review of C.A.R. trade policies as they formulate measures to address internal and external barriers to trade. These measures are likely to include developing trade policies consistent with the C.A.R.'s participation in regional trade and other preferential arrangements, export promotion, trade facilitation and improving standards, and policies aimed at enhancing the investment climate.

\section{Finally, the authorities will establish clear rules and regulations to attract} foreign direct investment and increase the contribution of the natural resource sector to national income. Reviving private sector activity is paramount because the government itself lacks the technical and financial capacity to exploit the country's forest and mineral wealth. The government therefore plans to revise the regulatory system to better protect investor rights, enhance governance over the management of forestry and mineral resources, and ensure that the state gets a fair return on their exploitation. In the same vein, the government will begin to address the problems associated with poor performance of state-owned enterprises, including through cost recovery pricing and management reforms.

\section{Capacity Building}

28. To ensure the smooth implementation of the policy framework, extensive technical assistance from development partners will be required. A variety of technical assistance is being delivered and the authorities have made effective use of the guidance provided. The assistance includes areas that will complement the proposed PRGF arrangement, such as enhancing governance in the natural resource sector, budget and treasury management, civil service reform, supporting the social sector (health and education), and development of the PRSP (see Box 2, which details donor involvement in the C.A.R., including technical assistance). They expect the C.A.R. to be a heavy user of the Central African Technical Assistance Center but further support will also be needed in areas not covered by the AFRITAC, such as legal reform, the financial sector, the reform of public enterprises, and with poverty and social impact assessments. With the assistance of the AfDB, the government is actively pursuing efforts to strengthen external debt management. These efforts involve computerization, including software to undertake debt sustainability analysis and strengthen monitoring and reporting, and to develop a manual to guide the assessment and selection of public-investment projects. Data quality is adequate for program monitoring but the intensive level of donor involvement (including the Fund) in building statistical capacity remains appropriate. 


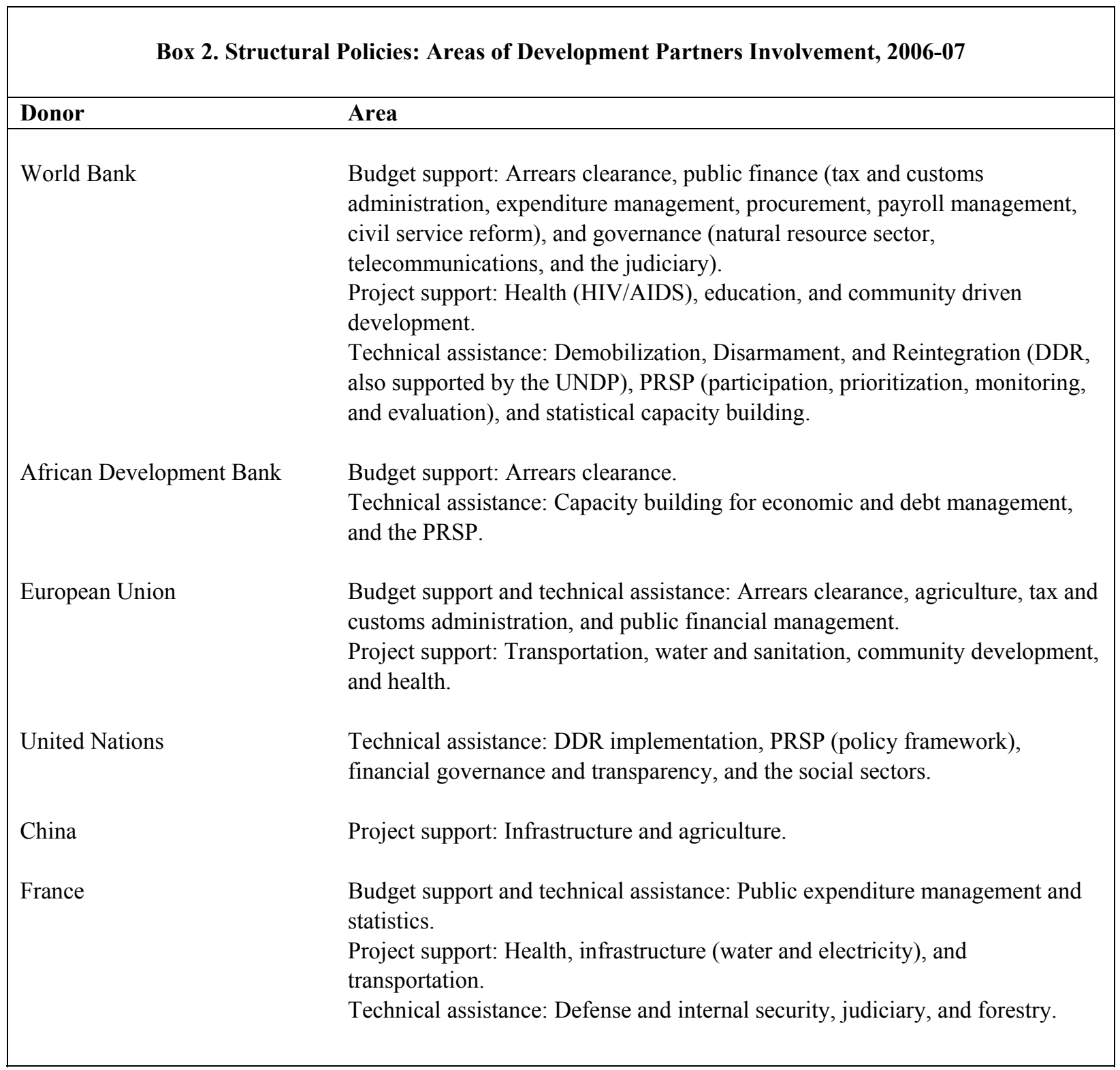

\section{E. The Poverty Reduction Strategy Paper}

\section{The authorities, like staff, consider the Poverty Reduction Strategy Paper} (PRSP) to be the appropriate instrument to articulate and address the obstacles to growth. The authorities are formulating the PRSP with the participation of civil society, nongovernmental organizations, private-sector representatives, and the donor community. Progress in finalizing the strategy has been slow primarily because of the time needed to ensure full regional participation and some delays in getting technical assistance in critical arrears (in particular, establishing a poverty profile).

30. Though the PRSP is not expected to be finished until mid-2007, the pillars of the government's strategy have already emerged and are reflected in the preparation status report, which is consistent with the proposed medium-term program: the consolidation 
of peace and security, a prerequisite for reviving investment and accelerating growth; macroeconomic stabilization; good governance, especially enhanced management of the public finances and the country's vast natural resources; and rehabilitation of basic infrastructure, both economic (power, water, roads) and social (health, education).

\section{The staff agrees with the thrust of the strategy elaborated so far but urges the authorities to refine the focus in several ways.}

- $\quad$ First, support the PRSP with a realistic, perhaps conservative, medium-term macroeconomic framework that recognizes the time it will take to transform the economy from post-conflict to prosperity and to address the obstacles to growth.

- Second, align the priorities and programs emerging in the strategy with the annual budget and an expenditure plan that recognizes that domestic resources are limited and there is uncertainty about the magnitude of future foreign assistance. Here the authorities stressed the importance of the new budget classification and nomenclature system as a tool for monitoring the allocation, execution, and reporting of public spending.

- $\quad$ Finally, with technical assistance, begin the difficult task of costing the PRSP so that resource requirements for meeting the MDGs can be effectively estimated.

\section{ECONOMic Policies For 2007}

32. In the first year of the program, the macroeconomic framework targets real GDP growth of 4 percent and a reduction of inflation to about 3 percent. The policies to support these objectives include:

- $\quad$ A 2007 budget that targets a domestic primary surplus of about 1 percent of GDP. This would be brought about by an increase of about 1 percent in the tax revenue-to-GDP ratio supported by a pickup in domestic economic activity and international trade, a positive contribution from petroleum-related taxation, and tax and customs administration reforms; a significant increase in nontax revenue from telecommunications licensing fees (about $1 / 2$ percent of GDP), and holding non-interest current expenditures to 8 percent of GDP. Outlays for poverty-related spending and capital expenditures are budgeted to increase in real terms, and some allowances have been made to accommodate increased spending on security if the situation deteriorates (about 0.1 percent of GDP). An increase in foreign grants and the restructuring of debt to the BEAC will allow for repayment of domestic debt equivalent to about $2 \frac{1}{2}$ percent of GDP. The government is also proposing to finance the domestic debt repayment through other means, such as domestic resources and negotiating a discount on the amounts due. Issuing an international tender to undertake an external audit for the validation of the domestic payments arrears is a prior action for the proposed program.

- Measures to strengthen tax administration, such as tightening controls over large taxpayers and extending these controls to small- and medium-size enterprises, raising tax 
compliance by enforcing disciplinary measures and intensifying audits, and aggressively collecting tax arrears (structural performance criterion for end-December 2007). On customs administration, the focus will be on unifying all activities to enhance monitoring (structural performance criterion for end-March 2007), bolstering the qualifications and training of customs officials, combating fraud and corruption, and addressing the audit recommendations of the one-stop customs window to raise its performance. Also, the government will establish formal procedures to regularly monitor sources of revenue to ensure that all receipts are dutifully reported and quickly lodged in the treasury account (structural performance criterion for end-March 2007).

- Measures to tighten control of public expenditures, such as accelerating the move to a single treasury account, eliminating extra-budgetary activities and the use of noncashbacked treasury checks (structural performance criterion for end-June 2007), and restricting the use of cash advances.

- Compliance with procedures for timely recapitalization by the private sector of a troubled commercial bank that could undermine financial stability.

- Revision of regulations in the forestry and mining sectors to improve governance and revenue reporting and enhance investment and consequently growth in the natural resource sector.

\section{Program Financing and Capacity to Repay the Fund}

\section{The C.A.R.'s financing requirements in 2007 amount to CFAF 17.1 billion} (Table 7), equivalent to about US\$31 million. The resources are expected to come mainly from grants from the World Bank (US\$19.6 million) and the AfDB (US\$4.5 million), and a rescheduling of official bilateral debt in the context of a Paris Club rescheduling. The staff understands that the authorities are making a good faith effort to reach a collaborative agreement with its other bilateral and commercial creditors; and it is expected that other bilateral and commercial debt will be rescheduled on terms at least as favorable as those granted by the Paris Club. Net financing from the Fund would be relatively low.

\section{Proposed access under the PRGF arrangement is SDR 36.2 million (65 percent}

of quota), to be disbursed in seven tranches. This level of access is appropriate considering the desirability of providing a positive net resource transfer flow to the C.A.R. during the program period and the limited availability of other financing. It recognizes the strength of the adjustment program while balancing the need to safeguard Fund resources. The first disbursement is set relatively high (SDR 17.6 million) to allow the government (i) to refinance the outstanding EPCA loans with PRGF resources to extend the repayment profile, thus increasing concessionality, and (ii) to hold sufficient resources in the SDR account to 
cover PRGF obligations falling due through the third quarter of next year. ${ }^{7}$ The authorities have also indicated their desire to maintain a balance in the SDR account that is sufficient to cover obligations falling due to the Fund over the coming six months, on a rolling basis. This is to ensure timely debt service payments to the Fund and safeguard the international community's assessment of C.A.R. creditworthiness.

\section{At the end of October 2006 C.A.R. credit outstanding to the Fund was} SDR 27.97 million (equivalent to 50.22 percent of quota), including SDR 12.53 million under the EPCA. With the proposed PRGF arrangement, the C.A.R.'s obligations will peak at SDR 38.5 million in 2009, representing about 33 percent of exports of goods and services. While recent payment performance has improved, C.A.R. repayments to the Fund have not always been timely. However, assuming strong program implementation, the country's external position should improve over time, including owing to debt relief. The authorities' intention to set aside resources in the SDR account is an assurance that debt service will be timely.

\section{Program Risks}

36. Even a moderate acceleration of growth depends critically on effective implementation of sound economic and financial policies. This itself will depend on strong program ownership, enhanced governance, and efforts to combat corruption.

Otherwise it is unlikely that business confidence and social stability can be restored; if they are not, there is a major risk to the outlook for the program. Here, the need to enhance governance is important to overcome donors' reluctance to provide budget support and the risk that corruption and self interest will slow the take-up of technical assistance that is critical for capacity building.

37. There is a risk of worsening instability in the north of the country, along the border with Chad and Sudan, and possibly in the south, related to the recent elections in the Democratic Republic of Congo (DRC). Since much of the country's livestock originates in the north, where there are continuing reports of conflict, destabilization there has implications for both growth and inflation. The recovery of economic activity in the C.A.R. also depends on unobstructed and efficient trade and commerce along the Oubangui River, which flows between the C.A.R. and the DRC. In the past, political and military disturbances in the DRC have had adverse consequences on economic activity along the river, and thus in the C.A.R. More generally, an environment of significant social instability would discourage a pickup in private investment and economic activity.

38. Finally, possible delays and lower volumes of foreign assistance are a concern. The level of aid projected in the 2007 budget provides for only a minimal level for

\footnotetext{
${ }^{7}$ Refinancing the EPCA loans is an effective way of providing more financial support to low-income post-conflict countries, as it would address maturity issues.
} 
government functioning and thus delays or shortfalls may have serious consequences. Also, substantially higher aid inflows would be needed for high growth and poverty reduction. Here, the authorities can mitigate the risks by demonstrating strong program ownership which could lead to stronger donor support.

\section{Staff Appraisal}

39. While the post-conflict situation is still fragile, the C.A.R. has made progress on many dimensions. The political and social situation is much improved, allowing the government to effect policies that support a recovery of economic activity that is gaining in strength. Though the financial situation is tight and the external environment is difficult, the authorities have been steadfast in imposing greater fiscal discipline and pursuing reform.

40. Recent program implementation under the Emergency Post-Conflict Assistance program has generally been satisfactory. Indeed, the execution of fiscal policy has been solid. The government has managed to pay wages and salaries and its other domestic liabilities in a more timely and regular manner, some domestic payments arrears have been cleared without new arrears accumulating, and there has been very little recourse to net domestic financing to alleviate the short-term constraints-unlike past episodes in similar circumstances. Structural reform has been narrowly focused, but aimed appropriately at critical areas-enhancing governance and transparency through public financial management reform and strengthening the judiciary to address corruption and financial crime.

\section{The authorities' medium-term economic and financial framework will form a} firm foundation for accelerating growth and reducing poverty. Fiscal consolidation to reduce the overhang of domestic debt will reinforce, and provide further room for, spending in critical areas. Here the anticipated increase in tax revenue will help alleviate the domestic resource constraints but donors also have an essential role to play, because even stepped upefforts to mobilize domestic resources will not bring in enough to meet the financing required to reach the MDGs.

42. Making effective use of the limited public resources is key to better outcomes. In this regard, the program's emphasis on reforming public financial management is welcome. These reforms will help restore the budget as the sole fiscal instrument, support an improvement in resource allocation, and provide safeguards against the expenditure slippages that have adversely affected fiscal and external debt sustainability in the past.

43. Reviving the private sector is a necessary condition for strong growth. Here the authorities' intention of pursuing financial sector reforms aimed at development and stability is well regarded; in light of the mounting evidence of the clear link between financial development and growth and the potentially strong impact on alleviating poverty and income inequality. In the same vein, the intention to liberalize trade is welcome as an important avenue to diversify the economy and expand the export base. 


\section{Debt relief offers the potential for additional resources-but not in the near}

term. The C.A.R. is not servicing its external debt, except to the Fund, so relief ahead of the completion point under the enhanced HIPC Initiative and MDRI will yield only a small benefit. During this period, it would be well for the authorities to accelerate reform and program implementation which would make it possible for C.A.R. to reach the HIPC decision point in a timely manner.

\section{Though daunting, the obstacles to growth and poverty reduction are not}

insurmountable although risks remain. The conflict in the north may spill over into other parts of the country, jeopardizing the prospects for peace and social stability and higher aid inflows, and the economy is vulnerable to external shocks. However, recent performance provides evidence that the authorities are committed to economic reform and good policies, even when faced with difficult conditions. Here, financial and technical assistance from the international community can support the achievement of the program's goals.

46. Given the strength of the authorities' program, including the prior action to be taken, the staff supports their request for a three-year PRGF arrangement in an amount equivalent to SDR 36.2 million, and for a first disbursement in an amount equivalent to SDR 17.6 million upon the Executive Board's approval of this arrangement. 


\section{Central African Republic-Three-Year Arrangement Under the \\ Poverty Reduction and Growth Facility}

Attached hereto is a letter from the Prime Minister and Minister of Finance and Budget dated November 30, 2006 (the "Letter"), with an attached Memorandum of Economic and Financial Policies (the "Memorandum") and Technical Memorandum of Understanding (the "TMU"), requesting from the International Monetary Fund as Trustee of the Poverty Reduction and Growth Facility and Exogenous Shocks Facility Trust (the "Trustee") a threeyear arrangement under the Poverty Reduction and Growth Facility, and setting forth:

(a) the objectives and policies of the program that the authorities of the Central African Republic intend to pursue during the three-year period of the arrangement;

(b) the objectives, policies and measures that the authorities of the Central African Republic intend to pursue during the first year of the arrangement; and

(c) understandings of the Central African Republic with the Trustee regarding reviews that will be made of progress in realizing the objectives of the program and of the policies and measures that the authorities of Central African Republic will pursue for the second and third years of the arrangement.

To support these objectives and policies, the Trustee grants the requested three-year arrangement in accordance with the following provisions, and subject to the provisions applying to assistance under the Poverty Reduction and Growth Facility Trust.

1. (a) For a period of three years from December 22, 2006 to December 21, 2009, the Central African Republic will have the right to obtain loan disbursements from the Trustee in a total amount equivalent to SDR 36.2 million, subject to the availability of resources in the Poverty Reduction and Growth Facility Trust.

(b) Disbursements under this arrangement shall not exceed the equivalent of SDR 20.7 million until December 21, 2007 and the equivalent of SDR 26.9 million until December 21, 2008.

2. During the first year of the arrangement:

(i) the first disbursement, in an amount equivalent to SDR 17.6 million, will be available upon approval of the arrangement, at the request of the Central African Republic; and

(ii) the second disbursement, in an amount equivalent to SDR 3.1 million, will be available on or after September 28, 2007, at the request of the Central African Republic and subject to the paragraphs 4 and 5 below. 
3. The right of the Central African Republic to request disbursements during the second and third years of this arrangement shall be subject to such phasing and conditions as shall be determined at later reviews. The phasing and conditions for disbursements during the second year of the arrangement shall be determined at the time of the first review referred to in paragraph 4(c) of this arrangement.

4. The Central African Republic will not request the second disbursement specified in paragraph 2(ii) above:

(a) if the Managing Director of the Trustee finds that, with respect to the second disbursement, the data as of June 30, 2007 indicate that:

(i) the floor on total government revenue; or

(ii) the ceiling on wages, salaries and bonuses; or

(iii) the floor on domestic primary balance; or

(iv) the ceiling on accumulation of new government domestic arrears on wages and goods and services; or

(v) the changes in net claims of the commercial banking system on the government,

as set out in Table 1 of the Memorandum and further specified in the paragraphs 3-17 of the TMU was not observed; or

(b) if the Managing Director of the Trustee finds that

(i) with respect to the second disbursement, the Central African Republic, by February 28, 2007, has not carried out its intentions to complete the external audit of the operations of the one-stop customs window in Douala (Guichet Unique), as set out in Table 2 of the Memorandum and as further specified in paragraph 22 of the Memorandum; or

(ii) with respect to the second disbursement, the Central African Republic, by March 31, 2007, has not carried out its intentions to restructure customs administration activities under a single entity, which will report to the Minister of Finance, as set out in Table 2 of the Memorandum and as further specified in paragraph 22 of the Memorandum; or

(iii) with respect to the second disbursement, the Central African Republic, by March 31, 2007, has not carried out its intentions to implement a formal procedure to audit and report on a quarterly basis all sources of revenue accruing to the State, as set out in Table 2 of the Memorandum and as further specified in paragraph 23 of the Memorandum; or 
(iv) with respect to the second disbursement, the Central African Republic, by June 30, 2007, has not carried out its intentions to complete the external audit for the validation of the domestic payments arrears, which accrued during the period 1998-2004, as set out in Table 2 of the Memorandum and as further specified in paragraph 18 of the Memorandum; or

(v) with respect to the second disbursement, the Central African Republic, by June 30, 2007, has not carried out its intentions to (i) eliminate the stock of Treasury checks issued in 2005-06, (ii) eliminate the issuance of non-cash backed Treasury checks, and (iii) made a public announcement that the Treasury checks described in (i) and (ii) above will no longer be valid after September 30, 2007, as set out in Table 2 of the Memorandum and as further specified in paragraph 23 of the Memorandum; or

(c) until the Trustee has determined, with respect to the second disbursement, that the first review of the Central African Republic's program, referred to in paragraph 33 of the Memorandum has been completed.

5. The Central African Republic will not request any disbursement under this arrangement

(a) if, at any time during this arrangement, the government of the Central African Republic contracts or guarantees any new non-concessional external debt; or

(b) if, at any time during this arrangement, the government of the Central African Republic accumulates any new external payment arrears,

as set out in Table 1 of the Memorandum and as further specified in the TMU; or

(c) if the Central African Republic has:

(i) imposed or intensified restrictions on payments and transfers for current international transactions; or

(ii) introduced or modified multiple currency practices; or

(iii) concluded bilateral payments agreements that are inconsistent with Article VIII; or

(iv) imposed or intensified import restrictions for balance of payments reasons; or

(d) until the Trustee has determined that with regard to each disbursement, for so long as the Central African Republic has outstanding sovereign external payments arrears to private creditors, or by virtue of the Central African 
Republic's imposition of exchange controls there are non-sovereign external payment arrears, a financing assurances review has been completed.

6. When the Central African Republic is prevented from requesting disbursements under this arrangement because of paragraphs 4 and 5 above, such disbursements will be made available only after consultation has taken place between the Trustee and the Central African Republic and understandings have been reached regarding the circumstances in which the Central African Republic may request the disbursements.

7. In accordance with paragraph 30 of the Memorandum and paragraph 2 of the TMU, the Central African Republic will provide the Trustee with such information as the Trustee requests in connection with the progress of the Central African Republic in implementing the policies and reaching the objectives of the program supported by this arrangement.

8. In accordance with paragraph 6 of the Letter, during the period of this arrangement, the Central African Republic shall consult with the Trustee on the adoption of any measures that may be appropriate at the initiative of the Government or whenever the Managing Director of the Trustee requests such a consultation. Moreover, after the period of this arrangement and while the Central African Republic has outstanding financial obligations to the Trustee arising from loan disbursements under this arrangement, the Central African Republic will consult with the Trustee from time to time, at the initiative of the Government or whenever the Managing Director of the Trustee requests consultation, on the Central African Republic's economic and financial policies. These consultations may include correspondence and visits of officials of the Trustee to the Central African Republic or of representatives of the Central African Republic to the Trustee. 
Table 1. Central African Republic: Selected Economic and Financial Indicators, 2004-09

\begin{tabular}{|c|c|c|c|c|c|c|c|}
\hline & \multirow[t]{2}{*}{2004} & \multirow{2}{*}{$\begin{array}{r}2005 \\
\text { Est. }\end{array}$} & \multicolumn{2}{|c|}{2006} & 2007 & 2008 & 2009 \\
\hline & & & Prog. 1/ & Proj. & \multicolumn{3}{|c|}{ Proj. } \\
\hline & \multicolumn{7}{|c|}{ (Annual percentage change, unless otherwise indicated) } \\
\hline \multicolumn{8}{|l|}{ National income and prices } \\
\hline GDP at constant prices & 1.3 & 2.2 & 3.2 & 3.5 & 4.0 & 4.3 & 4.5 \\
\hline GDP at current prices & -0.6 & 4.7 & 6.1 & 7.5 & 6.5 & 6.9 & 7.1 \\
\hline GDP deflator & -1.9 & 2.4 & 2.7 & 3.8 & 2.5 & 2.5 & 2.5 \\
\hline \multicolumn{8}{|l|}{ Consumer prices } \\
\hline Yearly average & -2.2 & 2.9 & 2.3 & 5.1 & 3.1 & 2.3 & 2.4 \\
\hline \multicolumn{8}{|l|}{ Central government finance } \\
\hline Total revenue (including grants) & 23.1 & 12.2 & 12.6 & 13.6 & 25.3 & 0.4 & 8.6 \\
\hline Total expenditure & 9.2 & 28.9 & 0.1 & -16.7 & 10.6 & 8.5 & 8.9 \\
\hline \multicolumn{8}{|l|}{ Money and credit } \\
\hline Net domestic assets 2/ & 12.0 & 10.4 & 1.3 & 11.2 & 1.1 & $\ldots$ & $\ldots$ \\
\hline Domestic credit 2/ & 13.6 & 9.8 & 1.3 & -8.4 & 1.8 & $\ldots$ & $\ldots$ \\
\hline Broad money $2 /$ & 14.2 & 16.5 & 6.0 & 4.5 & 7.1 & $\ldots$ & $\ldots$ \\
\hline Velocity of broad money (end of period) & 6.3 & 5.6 & 6.5 & 5.8 & 5.8 & $\ldots$ & $\ldots$ \\
\hline \multicolumn{8}{|l|}{ External sector } \\
\hline Exports, f.o.b. (U.S. dollar basis) & -0.5 & 2.9 & 7.7 & 12.0 & 7.1 & 6.8 & 7.7 \\
\hline Export volume & -1.1 & -6.9 & 3.8 & 6.1 & 6.2 & 6.1 & 7.0 \\
\hline Imports, f.o.b. (U.S. dollar basis) & 17.0 & 8.9 & 8.0 & 11.3 & 10.8 & 9.8 & 10.1 \\
\hline Import volume & 7.7 & 1.4 & 5.7 & 7.8 & 8.3 & 8.5 & 9.0 \\
\hline Terms of trade (U.S. dollar basis) & -7.4 & 2.8 & 1.5 & 2.3 & -1.4 & -0.4 & -0.3 \\
\hline Nominal effective exchange rate & 1.7 & -0.2 & $\ldots$ & $\ldots$ & $\ldots$ & $\ldots$ & $\ldots$ \\
\hline \multirow[t]{2}{*}{ Real effective exchange rate } & -0.9 & 0.7 & $\cdots$ & $\ldots$ & $\ldots$ & $\ldots$ & $\ldots$ \\
\hline & \multicolumn{7}{|c|}{ (In percent of GDP, unless otherwise indicated) } \\
\hline Gross national savings & 1.7 & 6.0 & 4.4 & 4.6 & 7.1 & 6.7 & 6.5 \\
\hline Of which: current official transfers & 0.6 & 1.9 & 1.1 & 1.0 & 1.8 & 1.4 & 0.0 \\
\hline Gross domestic savings & -0.5 & 2.1 & 1.9 & 1.5 & 3.1 & 3.1 & 3.0 \\
\hline Government & 0.6 & 0.0 & 0.2 & 2.8 & 5.7 & 4.5 & 4.5 \\
\hline Private sector & -1.1 & 2.1 & 1.7 & -1.3 & -2.6 & -1.4 & -1.5 \\
\hline Consumption & 100.5 & 97.9 & 98.1 & 98.5 & 96.9 & 96.9 & 97.0 \\
\hline Government & 3.2 & 4.4 & 2.5 & 2.5 & 3.2 & 3.7 & 4.0 \\
\hline Private sector & 97.3 & 93.5 & 95.6 & 96.0 & 93.8 & 93.2 & 92.9 \\
\hline Gross investment & 6.1 & 8.8 & 8.3 & 7.9 & 9.7 & 10.1 & 10.4 \\
\hline Government & 2.0 & 4.0 & 2.8 & 2.3 & 3.5 & 3.4 & 3.6 \\
\hline Private sector & 4.1 & 4.9 & 5.6 & 5.6 & 6.2 & 6.6 & 6.8 \\
\hline Current transfers and factor income (net) & 2.2 & 3.9 & 2.5 & 3.1 & 4.0 & 3.6 & 3.5 \\
\hline External current account balance & -4.4 & -2.8 & -3.9 & -3.3 & -2.6 & -3.3 & -3.9 \\
\hline Overall balance of payments & -2.8 & -1.1 & -2.0 & -5.3 & -1.4 & -1.7 & -1.8 \\
\hline \multicolumn{8}{|l|}{ Central government finance } \\
\hline Total revenue (including grants) & 11.4 & 12.2 & 10.8 & 12.9 & 15.1 & 14.2 & 14.4 \\
\hline Total expenditure & -13.5 & -16.7 & -12.1 & -12.9 & -13.4 & -13.6 & -13.8 \\
\hline \multicolumn{8}{|l|}{ Overall balance (commitment basis) } \\
\hline Excluding grants & -5.5 & -8.5 & -3.3 & -4.0 & -3.1 & -2.7 & -2.5 \\
\hline Including grants & -2.2 & -4.5 & -1.3 & 0.0 & 1.7 & 0.6 & 0.6 \\
\hline Domestic primary balance 3 / & -2.7 & -3.5 & 0.5 & 0.4 & 1.1 & 1.1 & 1.1 \\
\hline Basic balance 4/ & -3.9 & -4.4 & -0.7 & -1.6 & 0.3 & 0.4 & 0.5 \\
\hline External public debt before debt relief & 82.5 & 79.1 & 77.0 & 74.4 & 68.2 & 63.8 & 59.6 \\
\hline Net present value of total debt $5 /$ & 531.6 & 514.8 & 500.5 & 489.3 & 463.8 & 448.5 & 434.3 \\
\hline Scheduled debt-service ratio 5/ & 21.8 & 22.3 & 21.5 & 21.6 & 22.2 & 23.0 & 22.1 \\
\hline Actual debt-service ratio 5/ & 1.7 & 3.1 & 21.5 & $\ldots$ & $\ldots$ & $\cdots$ & $\ldots$ \\
\hline \multicolumn{8}{|l|}{ Gross official foreign reserves } \\
\hline (in millions of U.S. dollars, end-of-period) & 148.4 & 147.1 & 140.6 & 140.0 & 148.1 & 152.5 & 157.0 \\
\hline (in months of imports, f.o.b.) & 11.8 & 12.0 & 10.6 & 9.7 & 9.5 & 8.9 & 8.3 \\
\hline Nominal GDP (in billions of CFA francs) & 690.6 & 723.0 & 769.3 & 777.0 & 827.9 & 885.2 & 948.1 \\
\hline Exchange rate (average; CFA francs per U.S. dollar) & 528.3 & 527.5 & $\ldots$ & $\ldots$ & $\ldots$ & $\ldots$ & $\ldots$ \\
\hline
\end{tabular}

Sources: C.A.R. authorities; and IMF staff estimates and projections.

1/ Program supported by the ECPA policy, approved in January 2006.

$2 /$ In percent of broad money at beginning of the period.

3/ Excludes interest payments, foreign-financed investment, and grants.

4/ Excludes foreign-financed investment and grants.

$5 /$ In percent of exports of goods and services. 


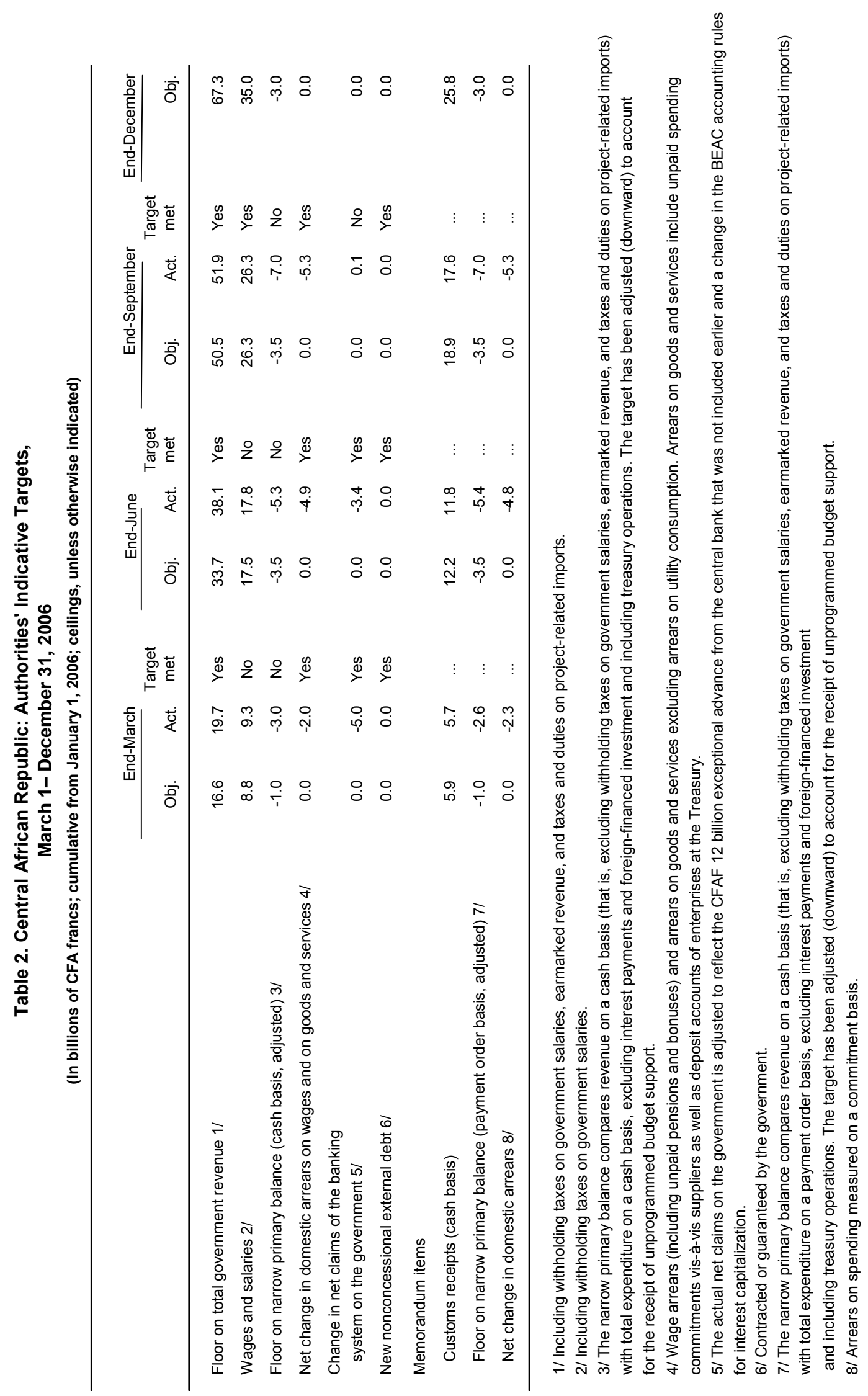


Table 3. Central African Republic: Central Government Operations, 2004-09 (In billions of CFA francs, unless otherwise indicated)

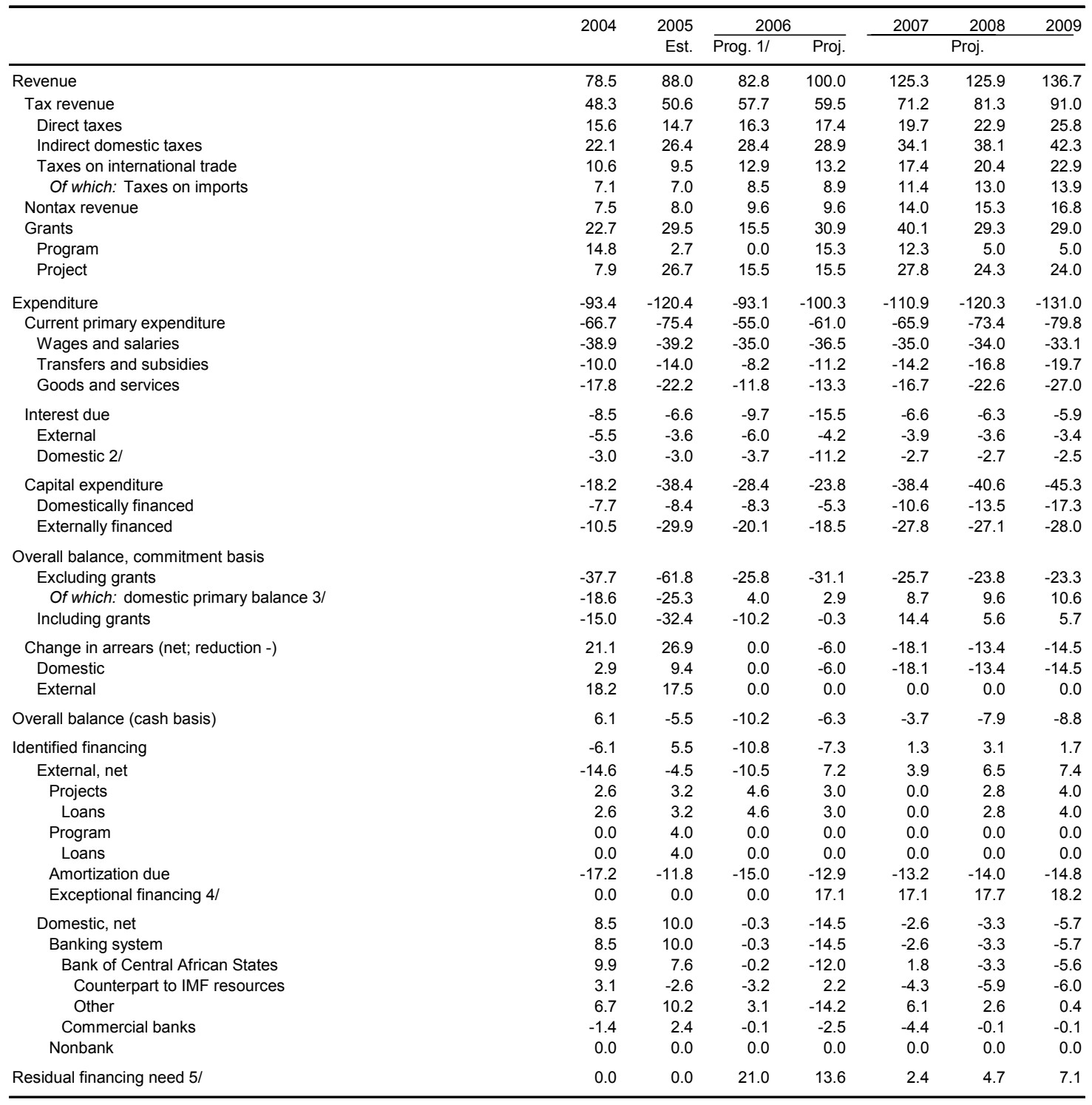

Sources: C.A.R. authorities; and IMF staff estimates and projections.

1/ Program supported by the ECPA policy, approved in January 2006.

2/ Increase in 2006 reflects the counterpart for the capitalization of unpaid interest due to change in BEAC accounting rules.

3/ Excludes interest payments, foreign-financed investment, and grants.

4/ This corresponds to the financing required to service external debt falling due. It does not reflect the gross impact of the World Bank and African

Development Bank arrears clearance operations equivalent to about $\$ 62.4$ million and $\$ 42.8$ million respectively, which will be financed by grants in late 2006 .

5/ Except for 2006 Prog., this gap is equivalent to the proposed disbursement under the PRGF arrangement. For 2006 Prog. it corresponds

to external debt service. 
Table 4. Central African Republic: Central Government Operations, 2004-09 (In percent of GDP)

\begin{tabular}{|c|c|c|c|c|c|c|c|}
\hline & \multirow[t]{2}{*}{2004} & \multirow{2}{*}{$\begin{array}{r}2005 \\
\text { Est. }\end{array}$} & \multicolumn{2}{|c|}{2006} & 2007 & 2008 & 2009 \\
\hline & & & Prog. 1/ & Proj. & \multicolumn{3}{|c|}{ Proj. } \\
\hline Revenue & 11.4 & 12.2 & 10.8 & 12.9 & 15.1 & 14.2 & 14.4 \\
\hline Tax revenue & 7.0 & 7.0 & 7.5 & 7.7 & 8.6 & 9.2 & 9.6 \\
\hline Direct taxes & 2.3 & 2.0 & 2.1 & 2.2 & 2.4 & 2.6 & 2.7 \\
\hline Indirect domestic taxes & 3.2 & 3.6 & 3.7 & 3.7 & 4.1 & 4.3 & 4.5 \\
\hline Taxes on international trade & 1.5 & 1.3 & 1.7 & 1.7 & 2.1 & 2.3 & 2.4 \\
\hline Of which: Taxes on imports & 1.0 & 1.0 & 1.1 & 1.1 & 1.4 & 1.5 & 1.5 \\
\hline Nontax revenue & 1.1 & 1.1 & 1.3 & 1.2 & 1.7 & 1.7 & 1.8 \\
\hline Grants & 3.3 & 4.1 & 2.0 & 4.0 & 4.8 & 3.3 & 3.1 \\
\hline Program & 2.1 & 0.4 & 0.0 & 2.0 & 1.5 & 0.6 & 0.5 \\
\hline Project & 1.1 & 3.7 & 2.0 & 2.0 & 3.4 & 2.7 & 2.5 \\
\hline Expenditure & -13.5 & -16.7 & -12.1 & -12.9 & -13.4 & -13.6 & -13.8 \\
\hline Current primary expenditure & -9.7 & -10.4 & -7.1 & -7.9 & -8.0 & -8.3 & -8.4 \\
\hline Wages and salaries & -5.6 & -5.4 & -4.5 & -4.7 & -4.2 & -3.8 & -3.5 \\
\hline Transfers and subsidies & -1.4 & -1.9 & -1.1 & -1.4 & -1.7 & -1.9 & -2.1 \\
\hline Goods and services & -2.6 & -3.1 & -1.5 & -1.7 & -2.0 & -2.6 & -2.8 \\
\hline Interest due & -1.2 & -0.9 & -1.3 & -2.0 & -0.8 & -0.7 & -0.6 \\
\hline External & -0.8 & -0.5 & -0.8 & -0.5 & -0.5 & -0.4 & -0.4 \\
\hline Domestic 2/ & -0.4 & -0.4 & -0.5 & -1.4 & -0.3 & -0.3 & -0.3 \\
\hline Capital expenditure & -2.6 & -5.3 & -3.7 & -3.1 & -4.6 & -4.6 & -4.8 \\
\hline Domestically financed & -1.1 & -1.2 & -1.1 & -0.7 & -1.3 & -1.5 & -1.8 \\
\hline Externally financed & -1.5 & -4.1 & -2.6 & -2.4 & -3.4 & -3.1 & -3.0 \\
\hline \multicolumn{8}{|l|}{ Overall balance, commitment basis } \\
\hline Excluding grants & -5.5 & -8.5 & -3.3 & -4.0 & -3.1 & -2.7 & -2.5 \\
\hline Of which: domestic primary balance $3 /$ & -2.7 & -3.5 & 0.5 & 0.4 & 1.1 & 1.1 & 1.1 \\
\hline Including grants & -2.2 & -4.5 & -1.3 & 0.0 & 1.7 & 0.6 & 0.6 \\
\hline Change in arrears (net; reduction -) & 3.1 & 3.7 & 0.0 & -0.8 & -2.2 & -1.5 & -1.5 \\
\hline Domestic & 0.4 & 1.3 & 0.0 & -0.8 & -2.2 & -1.5 & -1.5 \\
\hline External & 2.6 & 2.4 & 0.0 & 0.0 & 0.0 & 0.0 & 0.0 \\
\hline Overall balance (cash basis) & 0.9 & -0.8 & -1.3 & -0.8 & -0.4 & -0.9 & -0.9 \\
\hline Identified financing & -0.9 & 0.8 & -1.4 & -0.9 & 0.2 & 0.4 & 0.2 \\
\hline External, net & -2.1 & -0.6 & -1.4 & 0.9 & 0.5 & 0.7 & 0.8 \\
\hline Projects & 0.4 & 0.4 & 0.6 & 0.4 & 0.0 & 0.3 & 0.4 \\
\hline Loans & 0.4 & 0.4 & 0.6 & 0.4 & 0.0 & 0.3 & 0.4 \\
\hline Program & 0.0 & 0.6 & 0.0 & 0.0 & 0.0 & 0.0 & 0.0 \\
\hline Loans & 0.0 & 0.6 & 0.0 & 0.0 & 0.0 & 0.0 & 0.0 \\
\hline Amortization due & -2.5 & -1.6 & -2.0 & -1.7 & -1.6 & -1.6 & -1.6 \\
\hline Exceptional financing 4/ & 0.0 & 0.0 & 0.0 & 2.2 & 2.1 & 2.0 & 1.9 \\
\hline Domestic, net & 1.2 & 1.4 & 0.0 & -1.9 & -0.3 & -0.4 & -0.6 \\
\hline Banking system & 1.2 & 1.4 & 0.0 & -1.9 & -0.3 & -0.4 & -0.6 \\
\hline Bank of Central African States & 1.4 & 1.1 & 0.0 & -1.5 & 0.2 & -0.4 & -0.6 \\
\hline Counterpart to IMF resources & 0.5 & -0.4 & -0.4 & 0.3 & -0.5 & -0.7 & -0.6 \\
\hline Other & 1.0 & 1.4 & 0.4 & -1.8 & 0.7 & 0.3 & 0.0 \\
\hline Commercial banks & -0.2 & 0.3 & 0.0 & -0.3 & -0.5 & 0.0 & 0.0 \\
\hline Nonbank & 0.0 & 0.0 & 0.0 & 0.0 & 0.0 & 0.0 & 0.0 \\
\hline Residual financing need $5 /$ & 0.0 & 0.0 & 2.7 & 1.7 & 0.3 & 0.5 & 0.7 \\
\hline
\end{tabular}

Sources: C.A.R. author

1/ Program supported by the ECPA policy, approved in January 2006.

2/ Increase in 2006 reflects the counterpart for the capitalization of unpaid interest due to change in BEAC accounting rules.

3/ Excludes interest payments, foreign-financed investment, and grants.

4/ This corresponds to the financing required to service external debt falling due. It does not reflect the gross impact of the World Bank and African

Development Bank arrears clearance operations equivalent to about $\$ 62.4$ million and $\$ 42.8$ million respectively, which will be financed by grants in late 2006 .

5/ Except for 2006 Prog., this gap is equivalent to the proposed disbursement under the PRGF arrangement. For 2006 Prog. it corresponds

to external debt service. 


\section{Table 5. Central African Republic: Structural Measures under the 2006 EPCA Program}

\begin{abstract}
Measures
Revenue

Strengthen the management of large taxpayers by systematically following up on delinquent taxpayers, and, in particular, ensuring effective tracking of taxpayers who have been sent a reminder and applying deterrent penalties to non-filers.

Step up tax audits by setting more ambitious goals as to the quantity and quality of audits, to cover the taxpayer base more thoroughly. For June 2006, a target has been set of at least 20 full audits and 100 ad hoc inspections.

Continue to strengthen the Douala office, particularly by providing a computer link with the Cameroonian one-stop window and by conducting ad hoc inspections in collaboration with Cameroonian customs.

Install a copy of the SYDONIA++ customs computer software on a pilot basis, in preparation for a full migration from the SYDONIA software to the SYDONIA++ software.

Strengthen the examination of returns to identify businesses to which the flat tax (impôt libératoire) has been wrongly applied, by maintaining the target of at least 20 off-site examinations a year.
\end{abstract}

\section{Cash-flow management}

Limit and secure the issuance of Treasury checks against deposit accounts.

Close government bank accounts that are deemed unnecessary and provide justification for those that are kept open.

\section{Expenditure}

Identify any false academic qualifications presented by civil servants; detect any instances in which civil servants may have been assigned improper grades; and finalize the census of retired staff and adjust the payments database on the basis of the findings from the census.

Fully implement the unified civil service database (FURCA), so that both the Ministry of the Civil Service and the Payroll Office are using the same database.

Simplify the expenditure process including greater use of computerization.

\section{Governance and transparency}

Publish monthly data, with a time lag of not more than six weeks, on (i) the volume and value of forestry sector output produced, exported, and sold locally, together with the corresponding government revenue, and (ii) all licenses awarded or cancelled, the volume and value of diamonds produced and exported, and the corresponding government revenue.

Assess the work done by the firm responsible for the security of transit revenues at the port of Douala, and if the findings are unsatisfactory, issue a call for tenders so that a new contract can be awarded for doing this work.

Set up a website for publishing, on a regular basis, the government cash-flow plan, activity indicators in the forestry and diamond sectors, progress in the fight against corruption, and information on the awarding of procurement contracts based on the template agreed with the staff.

Submit the results of the verification of domestic arrears to an internationally recognized auditing firm for validation.

Date Status

March

Implemented

June

Implemented

June

Replaced by an international audit that is underway and wider customs reform.

June

Implemented

December

Implemented

March

Implemented

April

Implemented

March

Implemented

June

Implemented

June

Implemented

Beginning in Implemented February

April

Replaced by an international audit that is underway.

March Implemented
Replaced by Prior Action under the proposed PRGF arrangement to issue an international tender to undertake an audit. 
Table 6. Central African Republic: Monetary Survey, 2003-07

\begin{tabular}{|c|c|c|c|c|c|c|}
\hline & \multirow[t]{2}{*}{2003} & \multirow[t]{2}{*}{2004} & \multirow{2}{*}{$\begin{array}{r}2005 \\
\text { Est. 1/ }\end{array}$} & \multicolumn{2}{|c|}{2006} & \multirow{2}{*}{$\frac{2007}{\text { Proj. }}$} \\
\hline & & & & Prog. 2/ & Proj. & \\
\hline & \multicolumn{6}{|c|}{ (In billions of CFA francs at end of period) } \\
\hline Net foreign assets & 47.4 & 49.5 & 56.2 & 55.1 & 47.6 & 55.7 \\
\hline Bank of Central African States (BEAC) & 51.9 & 51.4 & 59.7 & 59.5 & 50.2 & 58.3 \\
\hline Operations account & 67.9 & 69.6 & 77.0 & 74.2 & 69.0 & 70.9 \\
\hline Use of IMF credit & -18.9 & -21.2 & -20.0 & -16.5 & -21.4 & -17.1 \\
\hline Other & 2.9 & 3.0 & 2.6 & 1.8 & 2.6 & 4.4 \\
\hline Commercial banks & -4.6 & -1.9 & -3.5 & -4.4 & -2.6 & -2.6 \\
\hline Net domestic assets & 49.2 & 60.7 & 72.2 & 63.1 & 86.6 & 88.1 \\
\hline Domestic credit & 102.2 & 115.4 & 126.1 & 117.7 & 115.3 & 117.8 \\
\hline Credit to the public sector & 52.8 & 60.2 & 72.0 & 60.8 & 58.3 & 55.7 \\
\hline Credit to central government (net) & 55.2 & 62.9 & 74.2 & 63.9 & 58.9 & 56.3 \\
\hline BEAC & 49.7 & 58.7 & 67.7 & 57.7 & 54.9 & 56.7 \\
\hline Current account & 17.1 & 25.1 & 32.1 & 30.4 & 39.3 & 39.3 \\
\hline Consolidated loans & 14.6 & 14.6 & 17.2 & 13.0 & 18.4 & 18.4 \\
\hline IMF (net) & 18.9 & 21.2 & 20.0 & 16.5 & 21.4 & 17.1 \\
\hline Deposits & -0.8 & -2.2 & -1.6 & -2.2 & -24.2 & -18.1 \\
\hline Commercial banks & 5.6 & 4.2 & 6.6 & 6.2 & 4.0 & -0.4 \\
\hline Credit to other public agencies (net) & -2.4 & -2.7 & -2.2 & -3.1 & -0.6 & -0.6 \\
\hline Credit to the economy & 49.4 & 55.2 & 54.1 & 56.9 & 57.0 & 62.0 \\
\hline Public enterprises & 8.4 & 6.7 & 5.6 & 6.7 & 5.6 & 5.1 \\
\hline Private sector & 41.0 & 48.4 & 48.5 & 50.2 & 51.4 & 57.0 \\
\hline Other items (net) & -53.1 & -54.6 & -53.9 & -54.6 & -28.8 & -29.7 \\
\hline Money and quasi money & 96.5 & 110.2 & 128.4 & 118.2 & 134.2 & 143.7 \\
\hline Currency & 70.4 & 81.3 & 89.9 & 81.2 & 92.5 & 94.1 \\
\hline Deposits & 26.1 & 28.9 & 38.6 & 37.0 & 41.7 & 49.6 \\
\hline Demand deposits & 15.1 & 16.4 & 23.8 & 21.0 & 24.4 & 30.7 \\
\hline Term and savings deposits & 11.1 & 12.5 & 14.7 & 16.0 & 17.3 & 18.9 \\
\hline \multicolumn{7}{|l|}{ Memorandum items: } \\
\hline Net domestic assets of the central bank & 20.7 & 32.3 & 38.6 & 25.1 & 50.9 & 46.0 \\
\hline Monetary base & 72.6 & 83.7 & 98.3 & 84.6 & 101.0 & 102.6 \\
\hline Nominal GDP & 694.7 & 690.6 & 723.0 & 769.3 & 777.0 & 827.9 \\
\hline \multicolumn{7}{|l|}{ Velocity (GDP/broad money) } \\
\hline End of period & 7.2 & 6.3 & 5.6 & 6.5 & 5.8 & 5.8 \\
\hline & \multicolumn{6}{|c|}{ (Annual change, in percent of beginning period broad money) } \\
\hline Net foreign assets & -8.0 & 2.2 & 6.1 & 4.7 & -6.7 & 6.0 \\
\hline Net domestic assets & -0.1 & 12.0 & 10.4 & 1.3 & 11.2 & 1.1 \\
\hline Net domestic credit & 2.5 & 13.6 & 9.8 & 1.3 & -8.4 & 1.8 \\
\hline Net credit to central government & 0.9 & 7.9 & 10.3 & -0.3 & -11.9 & -1.9 \\
\hline Credit to the economy & 0.0 & 6.0 & -1.0 & 1.9 & 2.3 & 3.8 \\
\hline Money and quasi money & -8.0 & 14.2 & 16.5 & 6.0 & 4.5 & 7.1 \\
\hline & \multicolumn{6}{|c|}{ (Annual percentage change) } \\
\hline Monetary base & -8.0 & 15.3 & 17.4 & 1.3 & 2.8 & 1.6 \\
\hline Credit to the economy & 0.1 & 11.6 & -1.9 & 3.9 & 5.3 & 8.8 \\
\hline Public enterprises & 4.7 & -20.2 & -16.2 & 0.0 & 0.0 & -10.0 \\
\hline Private sector & -0.8 & 18.2 & 0.1 & 4.4 & 6.0 & 10.9 \\
\hline
\end{tabular}

Sources: C.A.R. authorities; and IMF staff estimates and projections.

1/ Data for 2005 have been revised.

2/ Program supported by the ECPA policy, approved in January 2006. 
Table 7. Central African Republic: Balance of Payments, 2004-09

\begin{tabular}{|c|c|c|c|c|c|c|c|}
\hline & \multirow[t]{2}{*}{2004} & \multirow{2}{*}{$\begin{array}{r}2005 \\
\text { Est. }\end{array}$} & \multicolumn{2}{|c|}{2006} & 2007 & 2008 & 2009 \\
\hline & & & Prog. 1/ & Proj. & \multicolumn{3}{|c|}{ Proj. } \\
\hline & \multicolumn{7}{|c|}{ (In billions of CFA francs) } \\
\hline Current account & -30.5 & -20.5 & -30.1 & -25.3 & -21.5 & -29.6 & -37.3 \\
\hline Balance on goods & -7.5 & -12.1 & -11.6 & -12.9 & -16.7 & -20.6 & -24.5 \\
\hline Exports, f.o.b. & 66.0 & 67.6 & 74.5 & 75.3 & 78.8 & 83.7 & 89.8 \\
\hline wood products & 28.7 & 25.6 & 28.7 & 30.1 & 30.6 & 32.1 & 33.8 \\
\hline Imports, f.o.b. & -73.6 & -79.8 & -86.2 & -88.3 & -95.5 & -104.2 & -114.3 \\
\hline Petroleum products & -17.0 & -15.6 & -21.8 & -24.1 & -28.4 & -31.3 & -34.4 \\
\hline Public investment program & -1.9 & -5.0 & -3.8 & -6.3 & -6.9 & -10.6 & -11.5 \\
\hline Other & -54.7 & -59.2 & -60.6 & -57.9 & -60.2 & -62.3 & -68.3 \\
\hline Current transfers (net) & 18.2 & 28.1 & 21.6 & 25.0 & 33.5 & 32.1 & 32.4 \\
\hline Capital account & 18.5 & 15.4 & 7.4 & 22.7 & 25.5 & 16.5 & 16.4 \\
\hline Project grants $2 /$ & 3.8 & 12.7 & 7.4 & 7.4 & 13.2 & 11.5 & 11.4 \\
\hline Program grants & 14.8 & 2.7 & 0.0 & 15.3 & 12.3 & 5.0 & 5.0 \\
\hline Debt cancellation & 0.0 & 0.0 & 0.0 & 0.0 & 0.0 & 0.0 & 0.0 \\
\hline Financial account & -7.6 & -2.8 & 7.0 & -38.4 & -15.5 & -1.7 & 3.6 \\
\hline Public sector (net) & -14.6 & -4.5 & -10.5 & -9.9 & -13.2 & -11.2 & -10.8 \\
\hline Project disbursements & 2.6 & 3.2 & 4.6 & 3.0 & 0.0 & 2.8 & 4.0 \\
\hline Program disbursements & 0.0 & 4.0 & 0.0 & 0.0 & 0.0 & 0.0 & 0.0 \\
\hline Scheduled amortization & -17.2 & -11.8 & -15.0 & -12.9 & -13.2 & -14.0 & -14.8 \\
\hline Net official reserves movements $3 /$ & 1.4 & -9.6 & -5.3 & 10.3 & -8.0 & -7.7 & -8.0 \\
\hline Net IMF credit & 3.1 & -2.6 & -3.2 & 2.2 & -4.3 & -5.9 & -6.0 \\
\hline Purchases and loans & 4.4 & 0.0 & 0.0 & 5.4 & 0.0 & 0.0 & 0.0 \\
\hline Repayments (cash basis) & -1.3 & -2.6 & -3.2 & -3.2 & -4.3 & -5.9 & -6.0 \\
\hline Other reserves (increase -) & -1.8 & -7.1 & -2.1 & 8.0 & -3.7 & -1.8 & -1.9 \\
\hline Exceptional financing & 18.2 & 17.5 & 0.0 & 17.1 & 17.1 & 17.7 & 18.2 \\
\hline Debt rescheduling $4 /$ & & $\ldots$ & $\ldots$ & 17.1 & 17.1 & 17.7 & 18.2 \\
\hline Debt payments arrears (reduction -) & 18.2 & 17.5 & 0.0 & 0.0 & 0.0 & 0.0 & 0.0 \\
\hline Residual financing need $5 /$ & 0.0 & 0.0 & 21.0 & 13.6 & 2.4 & 4.7 & 7.1 \\
\hline Memorandum items: & \multicolumn{7}{|c|}{ (Annual percentage change, unless otherwise indicated) } \\
\hline Terms of trade (U.S. dollar basis) & -7.4 & 2.8 & 1.5 & 2.3 & -1.4 & -0.4 & -0.3 \\
\hline Unit price of exports (U.S. dollar basis) & 0.6 & 10.4 & 3.7 & 3.9 & 0.8 & 0.7 & 0.7 \\
\hline Unit price of imports (U.S. dollar basis) & 8.6 & 7.7 & 2.2 & 0.9 & 2.3 & 1.1 & 1.0 \\
\hline Gross official reserves & & & & & & & \\
\hline (in billions of CFA francs, end-of-period) & 72.6 & 79.6 & 76.0 & 71.6 & 75.3 & 77.2 & 79.1 \\
\hline (in months of imports, f.o.b.) & 11.8 & 12.0 & 10.6 & 9.7 & 9.5 & 8.9 & 8.3 \\
\hline Current account (in percent of GDP) & -4.4 & -2.8 & -3.9 & -3.3 & -2.6 & -3.3 & -3.9 \\
\hline Total stock of external arrears (in billions of CFA francs) & 177.0 & 193.5 & $\ldots$ & $\ldots$ & $\ldots$ & $\ldots$ & $\ldots$ \\
\hline Of which: arrears to multilateral creditors & 55.5 & 65.7 & $\ldots$ & $\ldots$ & $\ldots$ & $\ldots$ & $\ldots$ \\
\hline
\end{tabular}

Sources: C.A.R. authorities; and IMF staff estimates and projections.

1/ Program supported by the ECPA policy, approved in January 2006.

2/ A portion, 52.5 percent, of project grants is included under current transfers to reflect funds for technical assistance, expatriate military pensions, and UN programs.

3/ Based on definitions consistent with the IMF's Balance of Payments Manual (5th ed.).

4/ This corresponds to the financing required to service external debt falling due. It does not reflect the gross impact of the World Bank and African

Development Bank arrears clearance operations equivalent to about $\$ 62.4$ million and $\$ 42.8$ million respectively, which will be financed by grants in late 2006 .

5/ Except for 2006 Prog., this gap is equivalent to the proposed disbursement under the PRGF arrangement. For 2006 Prog. it corresponds

to external debt service. 


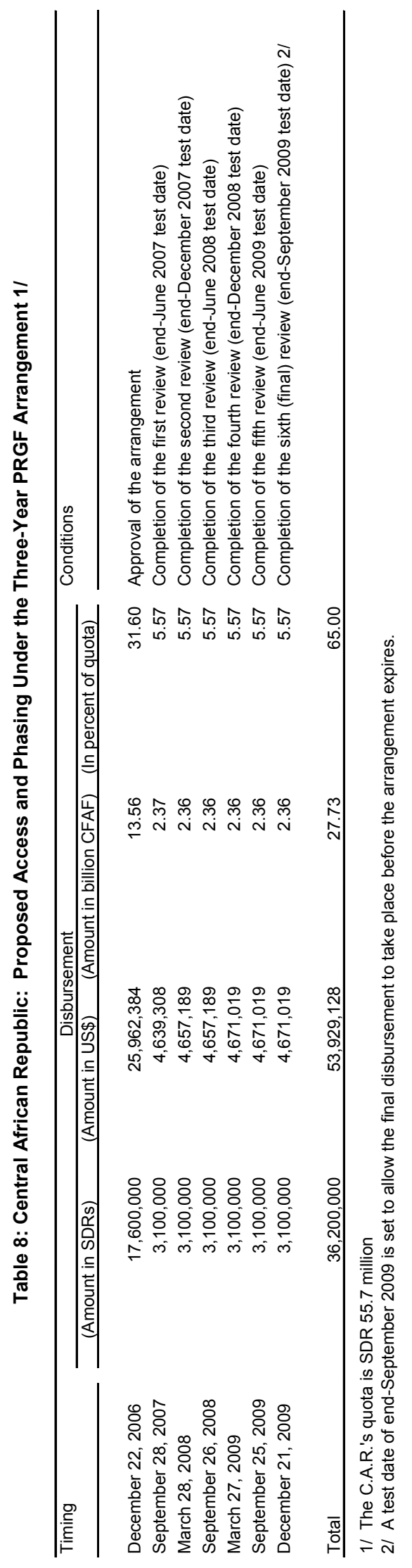


Table 9. Central African Republic: Indicators of Fund Credit, 2004-2010 1/

\begin{tabular}{|c|c|c|c|c|c|c|c|}
\hline & 2004 & 2005 & 2006 & 2007 & 2008 & 2009 & 2010 \\
\hline & & & \multicolumn{5}{|c|}{ Proj. } \\
\hline \multicolumn{8}{|l|}{ Outstanding use of Fund credit } \\
\hline In millions of SDRs & 28.4 & 25.1 & 33.0 & 31.2 & 32.5 & 38.5 & 36.9 \\
\hline In billions of CFA francs & 22.2 & 19.5 & 25.4 & 23.8 & 24.8 & 29.3 & 28.0 \\
\hline In percent of government revenue & 28.3 & 22.1 & 25.4 & 19.0 & 19.7 & 21.4 & 19.6 \\
\hline In percent of exports, f.o.b. & 33.6 & 28.8 & 33.7 & 30.2 & 29.6 & 32.6 & 29.3 \\
\hline In percent of external public debt & 3.4 & 2.9 & 3.8 & 3.7 & 4.0 & 4.8 & 4.7 \\
\hline In percent of GDP & 3.2 & 2.7 & 3.3 & 2.9 & 2.8 & 3.1 & 2.8 \\
\hline In percent of quota & 51.0 & 45.1 & 59.2 & 56.0 & 58.3 & 69.1 & 66.2 \\
\hline \multicolumn{8}{|c|}{ Repurchases, repayments, charges and interest due 2/ } \\
\hline In millions of SDRs & 1.8 & 3.4 & 4.4 & 5.2 & 5.1 & 3.4 & 1.8 \\
\hline In billions of CFA francs & 1.4 & 2.7 & 3.4 & 4.0 & 3.9 & 2.6 & 1.4 \\
\hline In percent of government revenue & 1.8 & 3.0 & 3.4 & 3.2 & 3.1 & 1.9 & 1.0 \\
\hline In percent of exports, f.o.b. & 2.1 & 3.9 & 4.5 & 5.0 & 4.6 & 2.9 & 1.4 \\
\hline In percent of debt-service payments & 5.7 & 14.8 & 14.3 & 13.8 & 13.4 & 8.6 & 4.7 \\
\hline In percent of GDP & 0.2 & 0.4 & 0.4 & 0.5 & 0.4 & 0.3 & 0.1 \\
\hline In percent of quota & 3.2 & 6.2 & 7.9 & 9.3 & 9.2 & 6.1 & 3.2 \\
\hline \multicolumn{8}{|l|}{ Net use of Fund credit } \\
\hline (in millions of SDRs) & 3.9 & -3.3 & 7.9 & -1.8 & 1.3 & 6.0 & -1.6 \\
\hline Disbursements & 5.6 & 0.0 & 24.6 & 3.1 & 6.2 & 9.3 & 0.0 \\
\hline Repayments & 1.6 & 3.3 & 16.7 & 4.9 & 4.9 & 3.3 & 1.6 \\
\hline
\end{tabular}

Sources: IMF, Finance Department; and staff estimates and projections.

1/ Includes the proposed PRGF arrangement and the authorities' intention of repaying all EPCA loans, as indicated in their Letter of Intent. 2/ Excluding SDR charges and assessments. 
Table 10. Central African Republic: Millennium Development Goals, 1990-2004

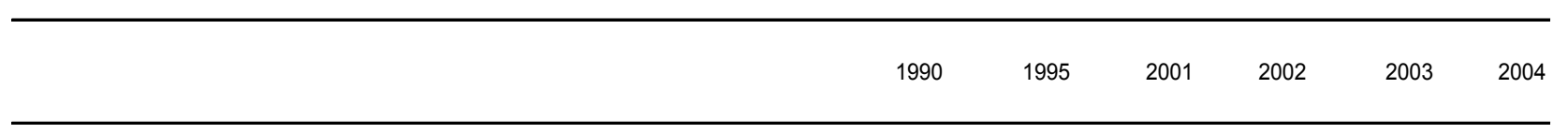

\section{Goal 1. Eradicate extreme poverty and hunger}

Target 1: Halve, between 1990 and 2015, the proportion of people whose income is less than one dollar a day.

1. Population below US\$1 a day (percent)

2. Poverty gap ratio at US\$1 a day (percent)

3. Share of income or consumption held by poorest 20 percent (percent)

66.6

$\quad 38.1$

$\quad 2.0$

Target 2: Halve, between 1990 and 2015, the proportion of people suffering from hunger

4. Prevalence of child malnutrition (percent of children under 5)

5. Population below minimum level of dietary energy consumption (percent)

\section{Goal 2. Achieve universal primary education}

Target 3: Ensure that, by 2015, children will be able to complete a full course of primary schooling

6. Net primary enrollment ratio (percent of relevant age group)

7. Percent of cohort reaching grade 5

8. Youth literacy rate (percent ages 15-24)

Goal 3. Promote gender equality and empower women

Target 4: Eliminate gender disparity in primary and secondary education, preferably by 2005 , and to all levels of education by 2015

9. Ratio of girls to boys in primary and secondary education (percent)

10. Ratio of young literate females to males (percent, ages 15-24)

11. Share of women employed in the nonagricultural sector (percent)

12. Proportion of seats held by women in the national parliament (percent)

\section{Goal 4. Reduce child mortality}

Target 5: Reduce by two-thirds, between 1990 and 2015, the under-5 mortality rate

13. Under-5 mortality rate (per 1,000$)$

14. Infant mortality rate (per 1,000 live births)

15. Immunization against measles (percent of children under 12 months)

Goal 5. Improve maternal health

Target 6: Reduce by three-fourth, between 1990 and 2015, the maternal mortality ratio

16. Maternal mortality ratio (modeled estimate, per 100,000 live births)

17. Proportion of births attended by skilled health personnel $\cdots$
...

$\cdots$

$\cdots$

58.5

47.0
58.9

60.1

...

4.0

180.0

115.0

62.0 $\cdots$
45.9

1,200

44.0
44.0 
Table 10. Central African Republic: Millennium Development Goals, 1990-2004 (concluded)

\begin{tabular}{llllll}
\hline & 1990 & 1995 & 2001 & 2002 & 2003 \\
\hline
\end{tabular}

Goal 6. Combat HIVIAIDS, malaria, and other diseases

Target 7: Halt by 2015, and begin to reverse, the spread of HIVIAIDS

18. HIV prevalence among females (percent, ages 15-24)

19. Contraceptive prevalence rate (percent of women ages 15-49)

20. Number of children orphaned by HIVIAIDS

$\begin{array}{rrrrrr}\ldots & \ldots & 13.5 & \ldots & 13.5 & 15.0 \\ \ldots & 14.8 & \ldots & \ldots & 28.0 & \ldots \\ \ldots & \ldots & 90,000.0 & \ldots & 110,000.0 & \ldots\end{array}$

Target 8: Halt by 2015 , and begin to reverse, the incidence of malaria and other

major diseases

21. Prevalence of death associated with malaria

22. Share of population in malaria risk areas using effective prevention and treatment

23. Incidence of tuberculosis (per 100,000 people)

24. Tuberculosis cases detected under DOTS (percent)

Goal 7. Ensure environmental sustainability

Target 9: Integrate the principles of sustainable development into policies and programs. Reverse the loss of environmental resources.

25. Forest area (percent of total land area)

26. Nationality protected areas (percent of total land area)

27. GDP per unit of energy use (PPP \$ per kg oil equivalent)

28. $\mathrm{CO} 2$ emissions (metric tons per capita)

29. Proportion of population using solid fuels

Target 10: Halve by 2015 proportion of people without access to safe drinking water 30. Access to improved water source (percent of population)

37.3

...

...

0.1

...

48.0

Target 11: Achieve by 2020 significant improvement for at least 100 million slum dwellers

31. Access to improved sanitation (percent of population)

32. Access to secure tenure (percent of population)

\section{Goal 8. Develop a Global Partnership for Development 1/}

Target 16. Develop and implement strategies for productive work for youth

45. Unemployment rate of population ages 15-24 (total)

Target 17: Provide access to affordable essential drugs

46. Proportion of population with access to affordable essential drugs

Target 18: Make available new technologies, especially information and communications

47. Fixed line and mobile telephones (per 1,000 people)

48. Personal computers (per 1,000 people)
24.0

25.0

27.0

27.0

Sources: World Bank, World Development Indicators database, 2003; and UNDP, Human Development Report 2005

1/ Targets 12-15 and indicators 33-44 are excluded because they cannot be measured on a country-specific basis. These are related to official development assistance, market access, and the HIPC initiative. 


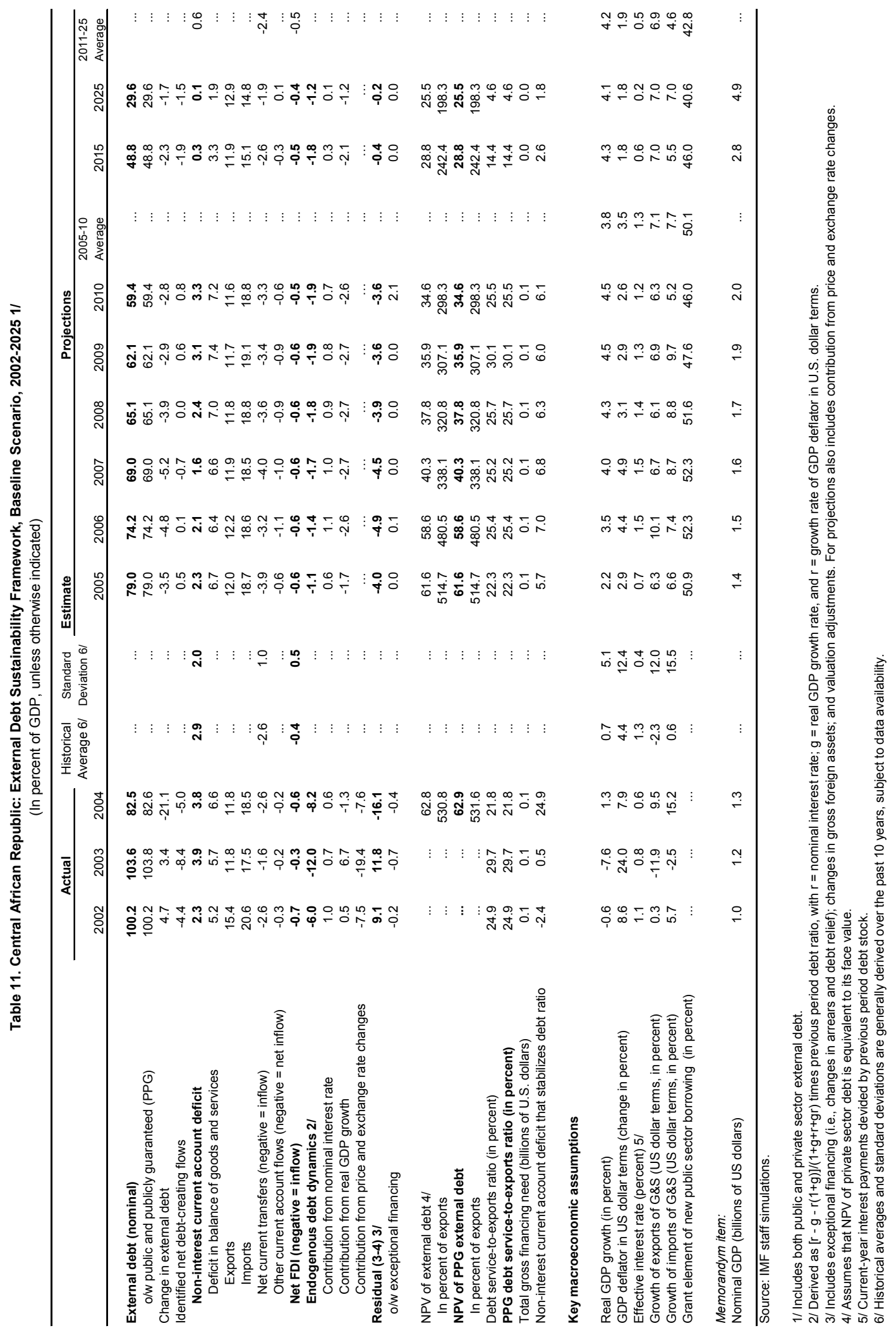


Table 12. Central African Republic: Sensitivity Analyses for Key Indicators of Public and Publicly Guaranteed External Debt, $2005-25$ (In percent)

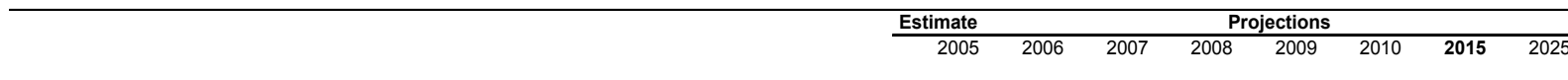

NPV of debt-to-GDP ratio

Baseline

A. Alternative Scenarios

A1. Key variables at their historical averages in 2006-25 1

A2. New public sector loans on less favorable terms in 2006-25 2

\section{B. Bound Tests}

B1. Real GDP growth at historical average minus one standard deviation in 2006-07

B2. Export value growth at historical average minus one standard deviation in 2006-07 3/

B3. US dollar GDP deflator at historical average minus one standard deviation in 2006-07

B4. Net non-debt creating flows at historical average minus one standard deviation in 2006-07 4/

B5. Combination of B1-B4 using one-half standard deviation shocks

B6. One-time 30 percent nominal depreciation relative to the baseline in $20065 /$

$\begin{array}{llllllll}62 & 59 & 40 & 38 & 36 & 35 & \mathbf{2 9} & 26 \\ & & & & & & & \\ 62 & 61 & 44 & 43 & 42 & 41 & \mathbf{4 1} & 51 \\ 62 & 59 & 49 & 47 & 46 & 45 & \mathbf{4 1} & 42 \\ & & & & & & & \\ & & & & & & & \\ 62 & 63 & 47 & 44 & 42 & 41 & \mathbf{3 4} & 30 \\ 62 & 60 & 44 & 42 & 40 & 38 & \mathbf{3 2} & 27 \\ 62 & 66 & 52 & 49 & 46 & 45 & \mathbf{3 7} & 33 \\ 62 & 60 & 43 & 40 & 38 & 37 & \mathbf{3 1} & 27 \\ 62 & 68 & 57 & 54 & 51 & 50 & \mathbf{4 1} & 35 \\ 62 & 82 & 57 & 53 & 50 & 49 & \mathbf{4 0} & 36\end{array}$

NPV of debt-to-exports ratio

Baseline

A. Alternative Scenarios

A1. Key variables at their historical averages in 2006-25 1/

A2. New public sector loans on less favorable terms in 2006-25 2

$\begin{array}{llllllll}515 & 480 & 338 & 321 & 307 & 298 & \mathbf{2 4 2} & 198 \\ & & & & & & & \\ 515 & 498 & 372 & 365 & 357 & 352 & \mathbf{3 4 9} & 400 \\ 515 & 481 & 413 & 401 & 393 & 389 & \mathbf{3 4 6} & 326 \\ & & & & & & & \\ & & & & & & & \\ 515 & 480 & 338 & 321 & 307 & 298 & \mathbf{2 4 2} & 198 \\ 515 & 634 & 595 & 566 & 542 & 527 & \mathbf{4 3 1} & 339 \\ 515 & 480 & 338 & 321 & 307 & 298 & \mathbf{2 4 2} & 198 \\ 515 & 489 & 360 & 342 & 328 & 318 & \mathbf{2 6 0} & 207 \\ 515 & 595 & 530 & 505 & 484 & 471 & \mathbf{3 8 5} & 300 \\ 515 & 480 & 338 & 321 & 307 & 298 & \mathbf{2 4 2} & 198\end{array}$

Debt service ratio

Baseline

A. Alternative Scenarios

A1. Key variables at their historical averages in 2006-25 1/

A2. New public sector loans on less favorable terms in 2006-25

B. Bound Tests

B1. Real GDP growth at historical average minus one standard deviation in 2006-07

B2. Export value growth at historical average minus one standard deviation in 2006-07 3/

B3. US dollar GDP deflator at historical average minus one standard deviation in 2006-07

B4. Net non-debt creating flows at historical average minus one standard deviation in 2006-07 4/

B5. Combination of B1-B4 using one-half standard deviation shocks

B6. One-time 30 percent nominal depreciation relative to the baseline in $20065 /$

$\begin{array}{llllllll}22 & 25 & 25 & 26 & 30 & 26 & \mathbf{1 4} & 5 \\ & & & & & & & \\ 22 & 21 & 22 & 27 & 25 & 23 & \mathbf{1 8} & 22 \\ 22 & 21 & 21 & 29 & 27 & 25 & \mathbf{2 0} & 21\end{array}$

Memorandum item:

Grant element assumed on residual financing (i.e., financing required above baseline) $6 /$

$\begin{array}{llllllll}22 & 21 & 21 & 25 & 22 & 19 & \mathbf{1 4} & 13 \\ 22 & 27 & 34 & 41 & 37 & 33 & \mathbf{2 3} & 22 \\ 22 & 21 & 21 & 25 & 22 & 19 & \mathbf{1 4} & 13 \\ 22 & 21 & 21 & 25 & 23 & 20 & \mathbf{1 4} & 14 \\ 22 & 25 & 30 & 36 & 33 & 29 & \mathbf{2 1} & 20 \\ 22 & 21 & 21 & 25 & 22 & 19 & \mathbf{1 4} & 13 \\ & & & & & & & \\ 44 & 44 & 44 & 44 & 44 & 44 & \mathbf{4 4} & 44\end{array}$

Source: IMF staff projections and simulations.

1/ Variables include real GDP growth, growth of GDP deflator (in U.S. dollar terms), non-interest current account in percent of GDP, and non-debt creating flows.

2/ Assumes that the interest rate on new borrowing is by 2 percentage points higher than in the baseline., while grace and maturity periods are the same as in the baseline.

$3 /$ Exports values are assumed to remain permanently at the lower level, but the current account as a share of GDP is assumed to return to its baseline level after the shock (implicitly assu an offsetting adjustment in import levels).

$4 /$ Includes official and private transfers and FDI.

5/ Depreciation is defined as percentage decline in dollar/local currency rate, such that it never exceeds 100 percent.

6/ Applies to all stress scenarios except for A2 (less favorable financing) in which the terms on all new financing are as specified in footnote 2 . 
Mr. Rodrigo de Rato

Managing Director

International Monetary Fund

Washington, DC 20431

USA

Dear Managing Director:

The democratic elections in mid-2005 marked an important transition for the Central African Republic. Since that time, the government has managed to improve the political and social situation which has allowed for an increased focus on economic management.

With the support of the International Monetary Fund (IMF) in particular, and the international community more generally, we have begun the difficult task of transforming our post-conflict economy and achieving sustained growth. While we recognize that this process is still in its early stages, we are encouraged by the results so far-a modest recovery is underway after a prolonged period of weak activity. We are determined to build on this performance and to establish the foundations for an acceleration of growth that will lead to a reduction in poverty and making progress towards the Millennium Development Goals.

In this regard, financial and technical assistance from the IMF is critical to the successful implementation of our medium-term economic strategy. This strategy is detailed in the Memorandum of Economic and Financial Policies (MEFP) attached to this letter, which is consistent with the government's Poverty Reduction Strategy Paper (PRSP) that is now being finalized. A PRSP preparation status report is being forwarded under a separate cover.

In support of our medium-term objectives and policies, the government of the Central African Republic hereby requests a three-year arrangement covering 2007-09 under the Poverty Reduction and Growth Facility (PRGF) in an amount equivalent to SDR 36.2 million (65 percent of quota), including a disbursement equivalent to SDR 17.6 million upon Executive Board approval of this arrangement. In line with our external debt management strategy, we will use these resources to repay outstanding-and relatively high cost-Emergency Post-Conflict Assistance loans and maintain sufficient resources in our SDR Account to meet PRGF obligations falling due until the third quarter of 2007-at which time, we hope to reach the Decision Point under the enhanced Heavily Indebted Poor Countries Initiative. Also, as a way of demonstrating the Central African Republic's commitment to maintain its creditworthiness, we intend to keep a balance in our SDR Account sufficient to cover obligations falling due to the IMF over the coming six months, on a rolling basis. 
We are aware that Executive Board discussion of the government's request for a three-year PRGF arrangement is contingent upon successful implementation of the prior action detailed in Table 2 of the attachment. Disbursements during the first year of the program will be linked to program reviews based on biannual quantitative performance criteria for end-June and end-December 2007 included in Table 1, and structural performance criteria and benchmarks for 2007 outlined in Table 2.

The government of the Central African Republic believes that the policies and measures set forth in the attached MEFP are adequate to achieve the objectives of the program, but we will take any further measures that may become appropriate for that purpose. During the implementation of the arrangement, we will consult with Fund staff on the adoption of any measures that may be appropriate, at the initiative of the government or whenever the Fund staff requests such a consultation.

The government intends to make the contents of this letter and those of the attached MEFP, as well as the staff report accompanying its request for a three-year PRGF arrangement, available to the public and authorizes the IMF to arrange for them to be posted on the IMF website, subsequent to Executive Board approval of its request.

We can assure you, Mr. Managing Director, that the government of the Central African Republic is determined to fully implement the program supported by the PRGF arrangement, and hopes to move to the Decision Point under the enhanced Heavily Indebted Poor Countries Initiative as soon as possible.

Yours sincerely,

/ s /

Elie Doté

Prime Minister

and Minister of Finance and Budget

Attachment

Memorandum of Economic and Financial Policies, 2007-09 


\section{Appendix I Attachment I: Memorandum of Economic and Financial Policies, 2007-09}

November 30, 2006

\section{INTRODUCTION}

1. Since the government took office in July 2005, a strengthening of political and social stability has allowed us to focus on macroeconomic and financial policies. This renewed focus has supported a modest economic recovery after a prolonged period of weak activity, which is also being helped by an improvement in the terms of trade. In the period ahead, we aim to consolidate macroeconomic stability and lay a strong foundation for an acceleration of growth and poverty reduction. This is essential if we are to make progress towards meeting the Millennium Development Goals (MDGs) and to maintain widespread support for economic and financial reform. In so doing, we recognize the challenges we face-the Central African Republic (C.A.R.) is a landlocked and primarily agriculture-based economy, with a narrow export base which makes it vulnerable to external shocks.

2. Our medium-term economic and financial strategy will be guided by a Poverty Reduction Strategy Paper (PRSP) that is now being prepared in consultation with stakeholders and our development partners. The PRSP will be finalized by mid-2007 and the main pillars of the strategy will include: the consolidation of peace and domestic security; macroeconomic stability; enhanced private-sector led growth, particularly through agricultural and natural resource development; good governance and effective use of public resources; and rehabilitation of the country's human and physical capital. Implementing this agenda will require firm economic management but also extensive financial and technical assistance from the international community.

\section{Economic Performance and Policies Since the Elections}

3. The government is cautiously optimistic that a sustained, albeit modest, economic recovery is underway. During 2005, real GDP growth was high enough to reverse the trend of declining real per capita income experienced since the late-1980s. For this year, real GDP growth of about $3 \frac{1}{2}$ percent should allow for some improvement in the standard of living. Economic activity has been supported by our main exports (diamonds and timber) and this activity has broadened to the secondary (manufacturing) and tertiary sectors (telecommunications, transport, and commerce), which is important for enhancing domestic resource mobilization from the formal sector. Inflation has been generally contained-reflecting mainly the benefits of the C.A.R.'s membership in the Central African Economic and Monetary Community (CEMAC) with its regional central bank (BEAC)-but it has accelerated recently, because of the increase in world oil prices that led to an upward adjustment of domestic petroleum product prices earlier this year, and supply constraints for foodstuffs. However, we anticipate that food supply conditions will improve, leading to a decline of inflation through the rest of the year. 
4. We have experienced a significant rebound in the volume of exports and an improvement in the terms of trade that has helped mitigate the impact of high world oil prices on the trade balance. Nonetheless, lower official transfers and a higher oil-import bill are likely to lead to a widening of the current-account deficit this year. Up to now, the deficit in the overall balance of payments was financed through the accumulation of external payments arrears, except to the Fund. However, the external payments arrears to the World Bank have now been cleared and we expect those to the African Development Bank to be cleared ahead of the Executive Board's discussion of our request. We continue to accumulate external payments arrears to official bilateral and commercial creditors but we have approached them to reschedule the C.A.R.'s external liabilities. In the period ahead, we intend to regularize our relations with all creditors, remain current with our external obligations, and to seek debt relief under the enhanced Heavily Indebted Poor Countries (HIPC) and Multilateral Debt Relief (MDRI) Initiatives.

5. The improvement in macroeconomic performance has been underpinned by a recent strengthening of fiscal policy. This strengthening is primarily due to our determined efforts to enhance public financial management, with the help of technical assistance from the Fund and other development partners. On the revenue side, we project an increase in tax collection above the target for this year (by about 0.2 percent of GDP), bringing tax revenue to the highest level since 2002. Reforms in tax administration, such as the audit and control of large taxpayers, efforts to improve tax payer compliance, and new tax measures have helped improve the situation. On the expenditure side, spending is projected to decline sharply this year because the government has taken measures to reduce the wage bill, there was a rollback of the election-related spending seen last year, and foreign-financed investment fell with the completion of several projects. However, there is likely to be some spending slippages related to external factors-associated with the regional conflict in the north of the country and increased petroleum-related subsidies designed to offset high world oil prices-and the decision to provide a small subsidy (0.2 percent of GDP) to jump-start the cotton sector. Nonetheless, in comparison with 2005, the fiscal stance is expected to improve significantly this year, moving from a primary deficit of $3 \frac{1}{2}$ percent of GDP to a domestic primary surplus of nearly $1 / 2$ percent.

6. Since the new government was formed, the focus of structural reform has been centered on areas critical to consolidating peace and security, and to bolster the credibility of fiscal policy. In this regard, we have made efforts to enhance public financial management as noted above, improve transparency of public sector operations, and strengthen the ability of the legal system to address financial and commercial crime. A wide range of data including on public finance, activity in the forestry and mining sectors, as well as information on progress in combating corruption and impunity, are now published and updated regularly on the government's web site. Also, the State Judicial Agent and the financial unit in the Ministry of Justice, which is in charge of prosecuting financial corruption, are operational, although their work is hampered by the lack of resources. Had resources and technical assistance been available, the authorities would have liked to pursue structural reforms in 
other areas, such as the restructuring of state-owned enterprises and the judiciary more generally. We intend to address these and other impediments to growth and poverty reduction in the period ahead, in consultation with the private sector through the recently established Permanent Consultation Framework.

\section{Medium-Term ObJectives ANd Policy Framework}

7. The PRSP provides the foundation for the government's medium-term policy framework, which aims at reviving business confidence and a resumption of private domestic and foreign investment. As will be elaborated in the PRSP, this policy framework is based on a number of considerations that are critical for accelerating growth and poverty reduction. First, we believe that establishing peace and strengthening security is essential. Second, while we recognize that private sector development will be needed to sustain growth over the medium term, a well functioning public sector is a key prerequisite. In this regard, the government must foster a change in the business culture and climate, through the timely and regular payment of its own liabilities, the recognition and enforcement of private property rights, intolerance of corruption both within and outside government, and enhancing the effectiveness of the judicial system. Third, while we face challenges on a number of fronts, financial, administrative, and institutional constraints will require the prioritization of our policy efforts which implies a narrow focus in a few key sectors, at least over the medium term. In this regard, a recovery of agriculture and enhancing conditions for investment in forestry and mining are imperative, as is allocating resources to reverse the decline in our human capital. A further priority is the rehabilitation of our basic economic and social infrastructure (especially the transportation network), which has suffered from many years of conflict and disinvestment. Unfortunately, our prospective resource envelope does not allow us to begin to address this situation in any meaningful way. We believe that well designed policies and strong program implementation will lead to resumption, and more importantly, a substantial increase in aid inflows.

8. With these considerations in mind, economic policies over the medium term will be aimed at:

- $\quad$ Achieving annual real GDP growth of 4-5 percent through 2009, which would result in per capita income growth of about 2 percent and modest progress toward reaching the income MDG.

- Maintaining annual inflation below the CEMAC convergence criterion of an average of 3 percent, consistent with the long-term inflation trend in the Euro area to help maintain the country's international competitiveness.

- Improving the environment for private sector development by: opening the economy to international trade; financial sector reforms that would increase credit to the private sector; by restructuring state-owned enterprises; and enhanced governance in the 
natural resource sector, including more reliable property rights and contract enforcement.

- $\quad$ Pursuing fiscal consolidation to gradually reduce the overhang of domestic debt that currently limits the room to maneuver in providing resources for growth-enhancing and poverty-reducing social policies. The government intends to accomplish this by maintaining domestic primary surpluses achieved with the help of stepped up efforts to mobilize domestic resources. We will repay costly commercial banks credit and refrain from further borrowing from commercial banks, and will use some external financing to retire domestic debt. This will require concerted efforts to enhance public financial management, reorient our expenditure priorities away from less productive uses and toward social spending, particularly on health and education, and reducing the budgeted level of wages and salaries through a reform of the civil service.

- $\quad$ Securing external debt sustainability by regularizing relations with external creditors and benefiting from debt relief. We will strive to improve external debt sustainability by pursuing grant financing and limiting foreign borrowing to only highly concessional loans.

- $\quad$ Building administrative and institutional capacity in a broad range of areas-policy design, monitoring and evaluation, public financial management, debt management, and statistics - to mitigate program risks and improve policy implementation and effectiveness. In this regard, we look forward to the opening of the central African Technical Assistance Center and invite more intensive technical assistance from our development partners.

9. The successful implementation of this medium-term program will provide a firm foundation for economic development of the C.A.R. On its own, however, the program is unlikely to lead to the acceleration of growth and poverty reduction needed to make rapid progress toward meeting the MDGs. This is because the domestic resource envelope will remain comparatively small, even with enhanced efforts to mobilize domestic resources. Moreover, until the C.A.R. reaches the completion point under the enhanced HIPC Initiative, debt relief will not free resources for public-investment spending since no debt service is currently being paid, other than to the Fund. A significant scaling up of aid inflows is required and we appeal to the international community for more support.

\section{The Program FOR 2007}

10. Building on the momentum generated during the past year, the challenge for 2007

will be to support a further increase in the rate of growth which we hope, will begin to lift the country out of poverty. Unfortunately, we expect a deterioration of the terms of trade next year which will create some headwinds for sustaining the recovery. Nonetheless, the prospects for increased output in the forest and mining sector, a rebound in agriculture supported by enhanced internal security, and externally-financed public investment should 
increase real GDP growth to about 4 percent, the highest rate since the late-1990s. Inflation is projected to fall to about 3 percent, as the impact of the pass-through of petroleum-product price increases earlier this year drop out of the consumer price index. To achieve these objectives, the fiscal stance will be tightened to address the overhang of domestic debt, financial policies will be directed at alleviating institutional and financial constraints to credit creation, external policies will aim at improving sustainability and trade liberalization, and structural policies will support public financial management reform.

\section{A. Fiscal Policy}

11. The government considers fiscal policy to be the cornerstone of its efforts to consolidate peace and social stability and to bring about an improvement in the business environment. We will maintain a fiscal stance appropriate to ensuring a reduction in domestic debt and the timely and regular payment of our domestic and external payments obligations. By reducing domestic debt-including payments arrears-we aim to regularize relations with creditors and reestablish the credibility of fiscal policy.

12. We have submitted to parliament a 2007 budget that is in line with understandings reached with Fund staff, and reflect the external arrears clearance operations that was recently conducted by the World Bank and is expected shortly from the African Development Bank, on our behalf. The budget for 2007 targets a domestic primary surplus of about 1 percent of GDP which is a significant improvement over last year, and nearly 5 percentage points higher than 2005 . This primary surplus would be brought about by an increase in the tax revenue-to-GDP ratio and firm control over public spending.

13. A key objective of fiscal policy is to raise the tax-revenue ratio, which is among the lowest in developing countries. The 2007 budget envisages an increase in tax collections by about 1 percent of GDP to 8.6 percent compared with 2006, driven by further reforms in tax and customs administration (see below). Non-tax revenue is expected to increase sharply by about $1 / 2$ percent of GDP, mainly because of receipts from telecommunication licensing fees. Also, the C.A.R.'s development partners have indicated their intention to increase the level of grants, which should be about 0.8 percentage points of GDP higher than this year. Overall, this will lead to an increase in total revenue from about 13 percent of GDP in 2006, to 15 percent next year.

14. For 2007, the government is maintaining compressed expenditures in recognition of the domestic resource constraints and limited aid inflows. Outlays on public sector energy consumption and foreign travel will be reduced, and the budgeted wage bill will be capped at CFAF 35 billion, which is the budgeted level for 2006. This cap implies a decline in the wage bill by about $1 / 2$ percent of GDP next year. The wage restraint does not take account of the staffing needs in the civil service-which in the health and education sectors are significant-but rather fiscal prudence as we bring the wage bill back in line with the overall expenditure envelope; and we will reassess the situation in the near future, in the context of 
reform of the civil service (developed with assistance from the World Bank). In particular, this wage restraint does not prevent the hiring of qualified teachers and health care workers who are needed to support improvement in the social sectors. Their employment could be accommodated within the budgeted wage ceiling for 2007 through attrition, early retirements, and the potential savings from completing the exercise of job reclassification to resolve improper grading and reducing salaries where credentials cannot be verified.

15. An increase in projected revenue and some spending cuts will, however, allow the government to boost spending in priority arrears. The 2007 budget envisages an increase in capital expenditures by about $1 \frac{1}{2}$ percent of GDP and in goods and service by about $1 / 2$ percent of GDP. The increase in the latter reflects expected spending for internal security, given the ongoing instability in the north of the country. The amount allocated (CFAF 3.3 billion) includes a contingency but any spending above this amount will be offset by cuts in other areas to maintain our overall fiscal objectives. We have allocated resources to support cotton producers (CFAF 250 million), which is being augmented by a European Union grant that can be used to help clear domestic payments arrears in this sector. The preliminary analysis in the PRSP is suggesting strongly that a revival of this sector is important for accelerating growth and strengthening social cohesion; cotton growing also has important synergies with the production of food crops, which is critical for alleviating poverty in rural areas.

16. The government will continue to provide financial support to vulnerable households (CFAF 1.5 billion) through 2007, to help shield them against high world oil prices. However, we are determined to reform the structure of petroleum product pricing and the way in which financial support to the poor is now being provided; the current policies are inefficient and ineffective in targeting support, because for some products it only benefits high income consumers. We have requested technical assistance from the Fund to help in the design of these reforms. By end-December 2007, we will implement a new petroleum pricing formula with parameters set to ensure full recovery of all costs, distribution margins, and taxes, and that avoids the need for future budget subsidies (structural performance criterion).

17. The revenue targets are ambitious and the expenditure envelope remains modest. However, if there is a shortfall in domestic resources we will take any measures necessary to achieve our overall fiscal objectives for next year.

18. The government will make concerted effort to reduce domestic debt which helps anchor our medium-term fiscal strategy. The domestic debt includes commercial bank overdrafts (1.6 percent of GDP at end-September 2006), the debt to the regional central bank (7.3 percent of GDP)-which we expect to be rescheduled shortly on concessional termspayments arrears (12.3 percent of GDP), and potential liabilities emerging from guarantees to state owned enterprises (which should be verified and validated shortly). The domestic arrears-including for wages and pensions and supplier's credits-which accrued during the period 1998-2004 were recently verified by an internal process and will be further validated 
by an external audit, which is expected to be completed by end-June 2007 (structural performance criterion). Once this audit is complete, the government will begin to clear these payments arrears.

19. We plan to clear the payments arrears through a number of means: domestic resources, external financial assistance, negotiating discounts on some of the amounts due, and using debt-for-equity swaps, possibly involving land or other public assets, although this option will require technical assistance to implement. We will ensure the transparency of the terms of repayment to the various groups of creditors and endeavor to treat them all on an equal basis. During 2007, we expect to repay domestic debt equivalent to nearly $2 \frac{1}{2}$ percent of GDP. This will be accomplished by a repayment of commercial bank overdrafts and the clearance of some payments arrears (equivalent to 2 percent of GDP), financed largely by grants.

\section{B. Public Financial Management}

20. An important aspect of the government's structural reform agenda and efforts to enhance governance will come about through enhanced public financial management.

21. Indeed, the ongoing reform of tax and customs administration, a broadening of the tax base, and improving taxpayer compliance will help to bolster tax collection. The government introduced new tax measures during the past year or so and tax rates are now relatively high in the C.A.R. Consequently, the government deems it appropriate to pursue administrative reforms, rather than new tax measures, to enhance domestic revenue mobilization. In line with IMF technical assistance, the government will pursue the following tax administration reforms to tighten controls over large-taxpayers and extend the efforts to small- and mediumsize enterprises: update the list of taxpayers (including public enterprises) and ensure the list covers all applicable taxes; reduce the rate of non-compliance of large enterprises through the effective implementation of disciplinary actions against delinquent taxpayers and further intensification of audits; apply the ceiling of CFAF 30 million turnover for the purpose of taxation of all businesses (individual and companies) without any exception and allow enterprises subject to the flat tax to opt out for the application of the regular tax regime; refrain from granting any new tax exemptions; and apply all the available mechanisms for recovering tax arrears. By end-December 2007, the government is determined to reduce the stock of tax arrears by at least CFAF 1 billion, net of uncollectible amounts (structural performance criterion).

22. With regard to customs administration, the government has recently taken action to address the persistent problems caused by the lack of training of customs officials and scope for corruption, which is evidenced by relatively poor revenue performance. Consequently, we have established a high level steering committee-Chaired by the President of the Republic-to design a reform, which will be implemented early next year. This reform will lead to a unification of all activities involved in customs administration (by end-March 2007, 
structural performance criterion), and include bolstering the qualifications and training of customs officials, combating fraud and corruption, and facilitating customs clearance, which together, should lead to a significant improvement in customs receipts. The reform of the customs administration will also be informed by the external audit of the one-stop customs window in Douala (Guichet Unique), which is due to be completed by end-February 2007 (structural performance criterion). The recently piloted valuation system, SYDONIA++, will be fully deployed starting in June 2007 and this will help improve customs valuation and limit discretion in this regard.

23. To enhance the monitoring and reporting of its fiscal activities, the government has recently adopted an Organic Budget Law which has guided the preparation of the 2007 budget. In the period ahead, we will adopt a new budget classification and nomenclature system and accounting rules that will strengthen the expenditure chain. In addition, we plan to:

- $\quad$ Put in place by end-March 2007 a formal procedure to audit and report on a quarterly basis all sources of revenue (tax and non-tax, including those for fees, licenses and permits in the natural resource sector) accruing to the state (structural performance criterion). These reports will be undertaken by the Inspector General of Finance and submitted to the Court of Accounts for verification and publication. We will begin an external audit (by end-September 2007) of all the sources of government revenue (collected through ministries and agencies) during the period July 2005 to endDecember 2006 to help ensure that all revenues have been dutifully reported to the state treasury, and to clarify areas where reporting can be strengthened (structural performance criterion). We will follow-up on the findings and recommendations on both the internal and external audits. Also, we will accelerate our participation in the Extractive Industries Transparency Initiative.

- $\quad$ Accelerate the move to a treasury single account (TSA) and deposit all government receipts in the TSA, including proceeds from natural resources fees, licenses, and permits;

- $\quad$ Disburse public resources only to pay for budgeted expenditures and fully report all government expenditures through the budget;

- $\quad$ By end-June 2007, gain better control over expenditures by eliminating the issuance of (new) non-cash backed Treasury checks and eliminate by the same date the stock issued in 2005-06 (structural performance criterion); the government will publicly announce that such Treasury checks will no longer be valid after end-September 2007. We will also restrict the practice of using cash advances, and requiring the full reporting of ex post expenditures; 
- $\quad$ Ensure that all revenues from the provinces are transferred fully and on a regular basis to the Treasury; and

- Implement (with the assistance of the World Bank) a new draft procurement code in line with international best practice.

\section{Monetary and Financial Sector Policies}

24. Monetary and exchange rate policy is conducted at the regional level by the Bank of Central African States (BEAC). The BEAC has been a source of stability for the C.A.R. and BEAC has been an important source of short-term financing in the past, although the cost has been relatively high. The government will avoid recourse to this financing, as well as reduce its net position toward the banking system over the program period.

25. Little progress has taken place in the C.A.R. in the recent past towards financial stability and development. Consequently, the banking sector remains weak and financial intermediation is among the lowest in the CEMAC region. In this regard, the authorities are making financial stability and development part of its Fund-supported program. This program proposes a national strategy for promoting financial development based on institutional reforms that could facilitate access to credit and remove obstacles to financial intermediation, and it has been informed by the recent Financial Sector Stability Assessment (FSSA) of the CEMAC. While it is acknowledged that the C.A.R.'s participation in the CEMAC implies that many institutional matters related to financial development are conducted by regional bodies and influenced by regional legal initiatives, it is also clear, as concluded in the regional FSSA, that there is considerable room for national initiative.

26. In 2007, the authorities intend to pursue:

- $\quad$ A legal and judiciary reform that could make credit collection more reliable, efficient and less costly. This would also involve by end-December 2007 the reform of commercial laws and civil procedures related to debt collection and bankruptcy, in line with the recommendations made by the recent regional FSSA (structural benchmark);

- $\quad$ The promotion of land surveys and modernization of the functioning of land and commercial registries, to facilitate the use of collateral for credit access;

- $\quad$ The implementation of an anti-money laundering/combating financing of terrorism (AML/CFT) framework outside the formal banking sector to prevent further disintermediation and informalization of financial services, in line with the recent regional Report on the Observance of Standards and Codes (ROSC, recommendations for AML/CFT); and 
- In close coordination with the regional regulator (COBAC) (i) the adoption of measures that would enhance stability in the financial sector, in particular, initiating the process of reconciliation and validation of potential liabilities of state owned enterprises toward commercial banks with a view to establishing options for their repayments, and (ii) compliance with established procedures for the timely recapitalization-without contributing government resources-of the troubled commercial bank (structural benchmark).

\section{External Sector Policies}

27. The C.A.R. has experienced a significant decline in external trade over the past several decades despite maintaining a relatively liberal exchange and trade system. While the country's landlocked nature and poor transport network inhibits trade, the government recognizes the import role played by trade policy. In this regard, the government intends to work with its CEMAC partners in the coming year to seek a reduction in the common external tariff and to coordinate more closely on reducing administrative barriers to regional trade, particularly along the main trade corridor between Bangui and Douala. Also, we intend to draw from the recommendations of the World Bank's Diagnostic Trade Integration Study (to be completed early next year) and the findings of the World Trade Organization's review of our trade policies during 2007. These studies will help us develop identify measures to eliminate both internal and external constraints to trade, and establish trade policies consistent with our participation in regional and other preferential trade agreements, improve trade facilitation, and enhance key elements of the investment climate.

28. The C.A.R. is in debt distress so achieving external sustainability is a high priority in the period ahead. External payments arrears have been be cleared to the World Bank and we expect those to the African Development Bank to be cleared ahead of the Executive Board's discussion of our request for a PRGF arrangement; and we will approach the Paris Club and other bilateral and commercial creditors to request a debt rescheduling once the PRGF is approved by the Executive Board.

29. Looking forward, the government is fully aware of the need to ensure prudent external debt management. With the assistance of the African Development Bank, the government will improve its debt management and project evaluation capacity. The government will also pursue grant financing wherever possible and will restrict its foreign borrowing only to loans with a grant element of 50 percent or more.

\section{E. Other Structural Policies}

30. The government is determined to improve the management of the natural resource sector. In this regard, in the coming year we will review the regulatory regime in the forestry sector and the mining code (in consultation with the World Bank), with the aim of establishing clear and predictable rules that guarantee the rights of investors, while maximizing the returns to the state. In the forestry sector, the legal and regulatory framework 
will be revised to strengthen management practices, enhance value added, adopt competitive and transparent criteria for attributing harvesting rights, and ensure that all public revenues from the sector are accounted for in the Treasury. In the mining sector, we will pursue efforts to upgrade the legal, regulatory and institutional settings, such as standardizing concession agreements, transparency over bonus payments, and full reporting of revenues from the sector in the Treasury. Also, in the coming year we will work to enhance the performance of state-owned enterprises, which suffer from poor financial and operating performance. One option being explored is the private-sector management of the water and electric utilities supported by tariff reforms and enhanced collections.

\section{F. Program Monitoring for 2007}

31. The program will be monitored through reviews based on biannual quantitative performance criteria for end-June and end-December 2007 (Table 1), and structural performance criteria and benchmarks for 2007 (Table 2). Detailed definitions and reporting requirements for all quantitative performance criteria and structural conditions are contained in the accompanying Technical Memorandum of Understanding (TMU, Attachment II). The government will make available to Fund staff all core data, appropriately reconciled and on a regular and timely basis, as specified in the TMU.

32. The government will implement one prior action ahead of the Executive Board's consideration of our request for a three-year arrangement under the PRGF. This prior action entails the issuance of an international competitive tender to undertake an audit for the validation of the domestic payments arrears accumulated between 1998-2004.

33. The first review under the PRGF arrangement is expected to be completed by September 28, 2007. 


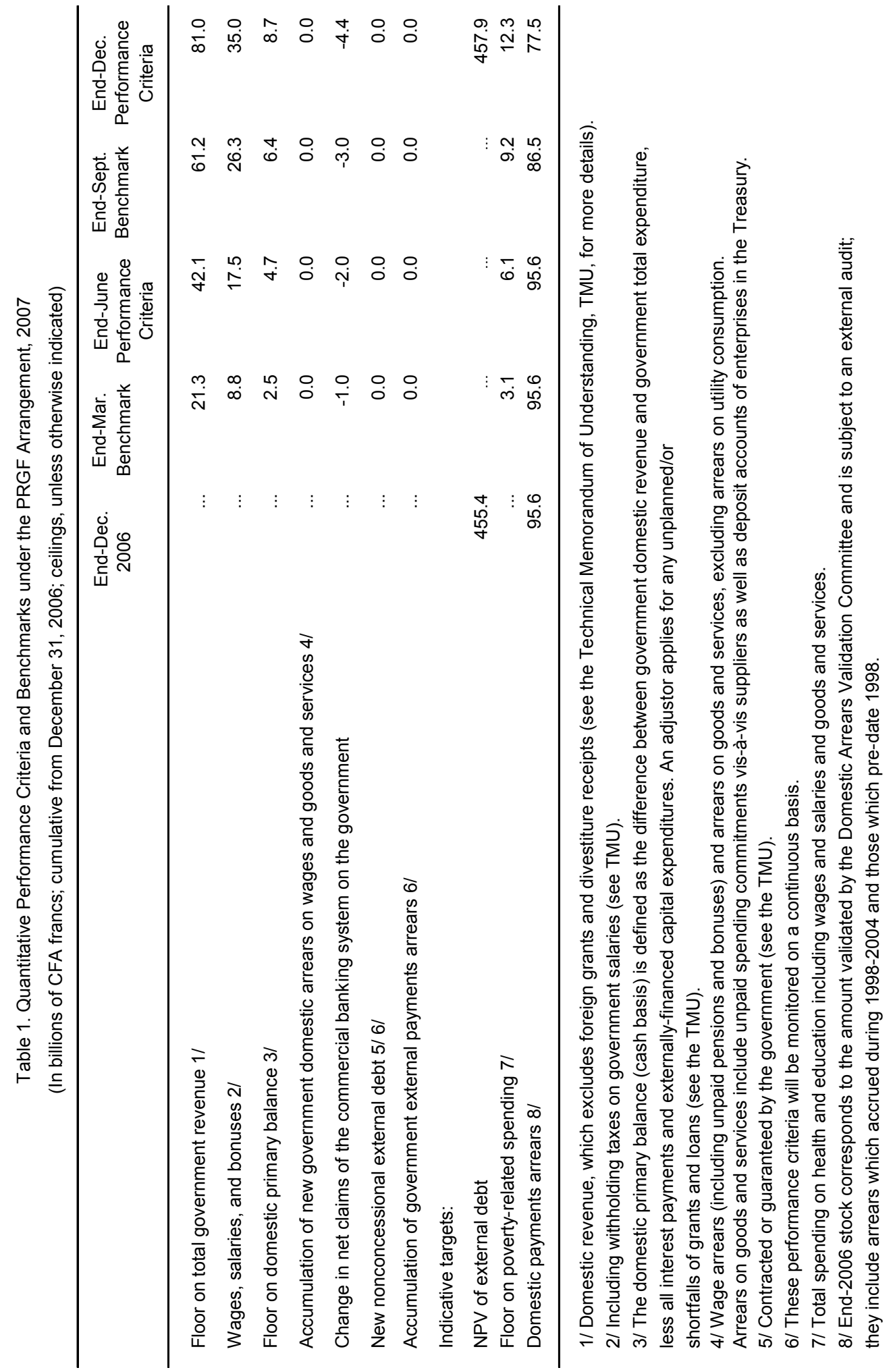


Table 2. Prior Action, Structural Performance Criteria and Benchmarks Under the PRGF Arrangement, 2007

\begin{tabular}{l} 
Measures \\
\hline Prior action \\
The issuance of an international competitive tender to undertake an external \\
audit for the validation of domestic payments arrears, which accrued during the \\
period 1998-2004.
\end{tabular}

\section{Structural performance criteria}

- $\quad$ By end-February 2007 complete the external audit of the operations of the onestop customs window in Douala (Guichet Unique).

- $\quad$ By end-March 2007, restructure (in consultation with Fund staff) the customs administration activities under a single entity, which will report to the Minister of Finance.

- $\quad$ By-end March 2007, implement a formal procedure to audit and report on a quarterly basis all sources of revenue (tax and non-tax, including those for fees, licenses, and permits in the natural resource sector) accruing to the State. The audits should be carried out by the Inspector General of Finance who will be given access to all relevant information to conduct the audits, and submitted to the Court of Accounts for verification and publication, no later than 2 months after the end of each quarter. The first of such audits should be published by May 2007.

- $\quad$ By end-June 2007 complete the external audit for the validation of the domestic payments arrears, which accrued during the period 1998-2004.

- $\quad$ By end-June 2007, eliminate the stock of treasury checks issued in 2005-06 and eliminate the issuance of non-cash backed treasury checks. The government will publicly announce that such treasury checks will no longer be valid after endSeptember 2007.

- $\quad$ By end-September 2007, begin an external audit of all the sources of government revenue (collected through ministries and agencies) during the period July-2005 to end-December 2006, to help ensure that all revenue has been dutifully reported to the state treasury, and to help clarify where reporting can be strengthened.

- $\quad$ By-end December 2007, implement a new petroleum product pricing formula with parameters set to ensure full recovery of all costs, distribution margins, and taxes, and that avoids the need for further budget subsidies.

- By-end December 2007, reduce the stock tax arrears by at least CFAF 1 billion, net of uncollectible tax arrears.

\section{Structural benchmarks}

- $\quad$ Continuous. The government will refrain from providing resources to recapitalize the troubled commercial bank.

- $\quad$ By end-December 2007, reform commercial laws and civil procedures relating to debt collection and bankruptcy in line with the recommendations in the regional Financial Stability Assessment Program completed in June 2006. 


\title{
ApPendix I AtTaChment II: TeChnical Memorandum OF Understanding
}

\author{
November 30, 2006
}

1. This Technical Memorandum of Understanding describes the definitions that are intended to clarify the measurement of the quantitative performance criteria and indicators in Table 1 of the Memorandum of Economic and Financial Policies, 2007-09, attached to the authorities' Letter of Intent. It also specifies the periodicity and deadlines for transmission of data to the staff of the International Monetary Fund (IMF) for program monitoring purposes. Unless otherwise specified, all quantitative performance criteria and indicative targets will be evaluated in terms of cumulative flows from December 31, 2006.

\section{Provision of data to the Fund}

2. Data with respect to all variables subject to performance criteria and indicative targets will be provided to Fund staff on a regular basis-with the timing indicated in Table 1 below-including any revisions, which will be transmitted in a timely manner. In addition, the authorities will consult with Fund staff on any information and data that become available, which are relevant for assessing or monitoring performance against the program's objectives but are not specifically defined in this memorandum.

\section{Definitions and computation}

3. Unless otherwise indicated, the government is defined as the central government of the Central African Republic (C.A.R.) and does not include local governments, the central bank, or any public entity with autonomous legal personality (i.e., wholly- or partially-owned state enterprises) not currently covered by the government consolidated financial operations table (tableau des operations financiers de l'Éta-TOFE).

4. Government domestic revenue is as reported in the TOFE and it includes offsetting operations in current revenue and expenditure-between the government and all suppliers of goods and services-excluding foreign grants and divestiture receipts. Government revenue includes all tax and non-tax revenue, as well as ear-marked revenue, checks for projectrelated customs duties, and withholdings from civil service wages and salaries actually paid.

5. Government expenditure is as reported in the TOFE and includes all earmarked spending, treasury operations, the domestic counterpart to foreign-financed projects, and offsetting operations. Poverty-related spending on health and education will be reported from the functional classification of government spending.

6. The government wage bill is monitored on a cash basis for all staff (permanent and temporary) of the civil service and the armed forces, including withholdings on behalf of the General Directorate of Tax Administration. The wage bill covers wages, salaries, and bonuses paid with a current lag of six months. For the purpose of the program, a lag length of 
more than seven months would result in an accumulation of wage arrears, while a decline in the lag length would be reflected in a reduction of wage arrears.

7. The domestic primary fiscal balance, on a cash basis, is defined as the difference between government domestic revenue and government expenditure, excluding all interest payments and externally-financed capital expenditure.

8. The accumulation of new government domestic payments arrears on wages and purchases of goods and services (excluding arrears on utility consumption) correspond to unpaid salaries, wages, pensions, and bonuses of civil servants and other government employees committed up to seven months prior to the current period, and to unpaid payment orders to suppliers of goods and services issued two months prior to the current period. The change in government domestic payments arrears on purchases of goods and services includes the deposit accounts of enterprises at the treasury resulting from unpaid expenses on goods and services supplied.

9. The end-of-period stock of net claims of the commercial banking system on the government is defined as the difference between deposits held by the government in commercial banks and outstanding loans and overdrafts.

10. The performance criterion on the contracting of new nonconcessional external debt applies to both short (with an original maturity of one-year or less) and medium- and longterm (with an original maturity of more than one year) external debt, contracted or guaranteed by the government. Purchases from the IMF are excluded from this limit.

11. For the purposes of this memorandum, the definitions of "debt" and "concessional borrowing" are as follows:

- $\quad$ The term "debt" has the meaning set forth in point No. 9 of the Guidelines on Performance Criteria with Respect to Foreign Debt, adopted by the Executive Board of the IMF on August 24, 2000 (Decision No. 12274-00/85, August 24, 2000) but also to commitments contracted or guaranteed for which value has not been received. For purposes of these guidelines, the term "debt" is understood to mean a current, that is, not contingent, liability, created under a contractual arrangement through the provision of value in the form of assets (including currency) or services, and which requires the obligor to make one or more payments in the form of assets (including currency) or services, at some future point(s) in time; these payments will discharge the principal and/or interest liabilities incurred under the contract. Debts can take a number of forms, the primary ones being as follows: (i) loans, that is, advances of money to the obligor by the lender made on the basis of an undertaking that the obligor will repay the funds in the future (including deposits, bonds, debentures, commercial loans, and buyers' credits) and temporary exchanges of assets that are equivalent to fully collateralized loans, under which the obligor is required to repay the funds, and usually pay interest, by repurchasing the collateral from the buyer in the future (such as repurchase agreements and official swap arrangements); 
(ii) suppliers' credits, that is, contracts where the supplier permits the obligor to defer payments until some time after the date on which the goods are delivered or services are provided; and (iii) leases, that is, arrangements under which property is provided that the lessee has the right to use for one or more specified period(s) of time that are usually shorter than the total expected service life of the property, while the lessor retains the title to the property. For the purpose of the guideline, the debt is the present value (at the inception of the lease) of all lease payments expected to be made during the period of the agreement, excluding those payments that cover the operation, repair, or maintenance of the property. Under the definition of debt set out above, arrears, penalties, and judicially awarded damages arising from the failure to make payment under a contractual obligation that constitutes debt are debt. Failure to make payment on an obligation that is not considered debt under this definition (e.g., payment on delivery) will not give rise to debt.

- Loan concessionality is assessed on the basis of the commercial interest reference rates (CIRRs) established by the Organization for Economic Cooperation and Development (OECD). A loan is said to be on concessional terms if, on the date the contract is signed, the ratio of the present value of the loan, calculated on the basis of the reference interest rates, to its nominal value is less than 50 percent (that is, a grant element of at least 50 percent, which does not apply to refinancing operations). For debts with a maturity exceeding 15 years, the ten-year reference interest rate published by the OECD is used to calculate the grant element. For shorter maturities, the six-month market reference rate is used. To both the 10-year and six-month averages of the reference rate, the following margins will be added: 0.75 percent for repayment periods of less than 15 years; 1 percent for 15-19 years; 1.15 percent for 20-29 years; and 1.25 percent for 30 years or more.

12. The concept of government for the purpose of the indicator on external debt includes government as defined in paragraph 3, administrative public institutions, public enterprises authorized to contract, guarantee, or accommodate nonconcessional borrowing, scientific and technical public institutions, professional public institutions, industrial and/or commercial public institutions, and local governments.

13. External payments arrears are deemed to accrue when undisputed interest or amortization payments of the government are not made within the terms of the contract, or in conformity with any future deferral agreed with the Paris Club or other bilateral and commercial creditors.

14. The net-present-value of external debt is estimated using the IMF's external Debt Sustainability template for Low-Income Countries.

15. The domestic payments arrears are understood to include those validated by the external audit undertaken during the first part of 2007 which accrued during 1998-2004 and those which pre-date 1998. These domestic payments arrears include wages and salaries and supplier's credits. 
16. The program exchange rate for the purposes of this memorandum is CFAF 655.957 per Euro and US\$ 1.47 per SDR.

\section{Adjuster}

17. The floor on the domestic primary fiscal balance (cash basis) will be adjusted downward to reflect the full amount of any unprogrammed foreign grants and/or external budget support (in the form of concessional loans with a grant element of at least 50 percent). This floor will adjusted upward by up to CFAF 3 billion per period, with a cumulative annual ceiling of CFAF 6 billion, for any shortfall in programmed foreign grants and/or external budget support. The net domestic financing for such a shortfall will be provided only through the regional central bank (BEAC). The projected foreign grants and external budget support for 2007 are detailed in Table 2 below. Quarterly differences between projected and actual foreign grants and external budget support will be converted to CFAFs at the average quarterly exchange rate during the period in question and cumulated to the test date. 


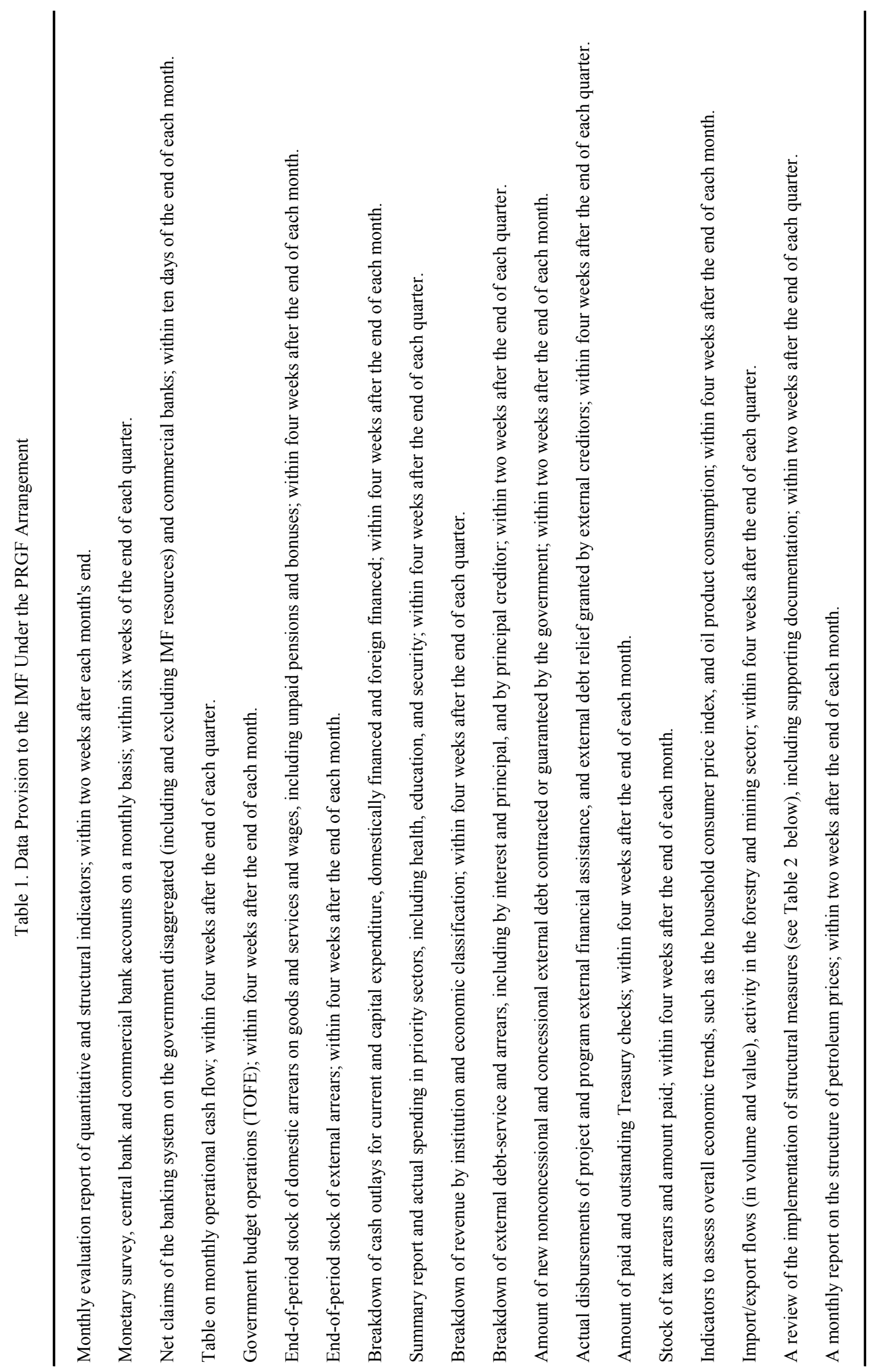


Table 2. Foreign Grants and Budget Support, 2007

(In billions of CFA francs, cumulative from December 31, 2006)

\begin{tabular}{lrrrr}
\hline & End-Mar. & End-June & End-Sep. & End-Dec. \\
& & & & 7.7 \\
\hline Grants & 7.7 & 7.7 & 0.0 & 12.3 \\
Concessional loans 1/ & 0.0 & 0.0 & 7.7 & 0.0 \\
Total & 7.7 & 7.7 & 12.3 \\
\hline
\end{tabular}

Sources: C.AR. Authorities; development partners; and Fund staff estimates.

$1 /$ Consisting of concessional loans with a grant element of at least 50 percent. 


\section{APPENDIX II: CENTRAL AFRICAN REPUbliC: RELATIONS WITH THE FUND}

(As of October 31, 2006)

I. Membership Status: Joined: 07/10/1963; Article VIII

II. General Resources Account:

Quota

Fund holdings of currency

Reserve position in Fund

\begin{tabular}{rrr} 
SDR million & & \%Quota \\
\hline 55.70 & 100.00 \\
68.08 & 122.23 \\
0.16 & 0.29
\end{tabular}

$\underline{\text { SDR million } \quad \text { A Allocation }}$

$9.32 \quad 100.00$

$0.54 \quad 5.77$

Net cumulative allocation

Holdings

IV. Outstanding Purchases and Loans:

PRGF arrangements

$\frac{\text { SDR million }}{15.44} \quad \frac{\text { \%Quota }}{27.72}$

$12.53 \quad 22.50$

V. Financial Arrangements:

Type

ESAF/PRGF

Stand-By Arrangement

SAF

\begin{tabular}{|c|c|c|c|}
\hline $\begin{array}{r}\text { Approval } \\
\text { date }\end{array}$ & $\begin{array}{r}\text { Expiration } \\
\text { date }\end{array}$ & $\begin{array}{l}\text { Amount } \\
\text { approved } \\
\text { (In millions of }\end{array}$ & $\begin{array}{l}\text { Amount } \\
\text { drawn } \\
\text { SDRs) } \\
\end{array}$ \\
\hline Jul 20, 1998 & Jan 19, 2002 & 49.44 & 24.48 \\
\hline Mar 28, 1994 & Mar 27, 1995 & 16.48 & 10.71 \\
\hline Jun 01,1987 & May 31, 1990 & 21.28 & 21.28 \\
\hline
\end{tabular}

VI. Projected Obligations to the Fund

(SDR million; based on existing use of resources and present holdings of SDRs):

\begin{tabular}{lccccc} 
& \multicolumn{5}{c}{ Forthcoming } \\
\cline { 2 - 6 } & 2006 & 2007 & 2008 & 2009 & 2010 \\
Principal & 0.00 & 5.59 & 7.68 & 7.95 & 5.08 \\
Charges/interest & $\underline{0.29}$ & $\underline{1.10}$ & $\underline{0.98}$ & $\underline{0.77}$ & $\underline{0.53}$ \\
Total & 0.29 & 6.69 & 8.66 & $\mathbf{8 . 7 2}$ & 5.61
\end{tabular}

VII. Implementation of HIPC Initiative: Not applicable.

VIII. Safeguards Assessments:

The Bank of the Central African States (BEAC) is the regional central bank of the Central African States, of which the Central African Republic is a member. A safeguards assessment of the BEAC was completed on August 30, 2004 and the main recommendations were reported in Country Report No. 05/424.

\section{Exchange Rate Arrangement}

The Central African Republic is a member of a monetary association with a common central bank, the Bank of Central African States (BEAC). The exchange system, common to all members, operates without restrictions on the making of payments and transfers for current international transactions. The CFA franc is pegged to the euro at the fixed rate of CFAF $655.957=€ 1$. On November 22, 2006, the rate of the CFA franc in terms of SDRs was SDR 1 = CFAF 758.06. 


\section{Article IV Consultations}

The Central African Republic is on the standard 12-month cycle for Article IV consultations. The last Article IV consultation was concluded on October 24, 2005.

\section{Recent Technical Assistance}

Date Department $\underline{\text { Purpose }}$

April 2001 FAD To follow up on the introduction of the VAT and discuss measures to improve tax and customs revenue collection.

Jan-Feb 2004 STA To assist the authorities in reviewing and updating the General Data Dissemination System (GDDS) and to provide technical assistance in government finance statistics.

March 2004 FAD To assist the authorities in the area of revenue administration.

April 2004 FAD To assist the authorities in the area of public expenditure management.

Aug-Oct 2004 FAD To assist the authorities improve tax administration.

Feb-Dec 2005 FAD To assist the authorities improve public expenditure management.

May 2005

FAD To follow up on implementation of tax administration reforms and review the progress made since the end of the three-month assignment of FAD tax expert.

Jun-July 2005 STA To assist the authorities improve government finance statistics.

July 2005 STA

To assist the authorities improve real sector data.

March-May 2006 FAD

To assist authorities in enforcing tax compliance and recovering tax arrears.

Sept-Oct 2006 STA To assist in the area of monetary and financial statistics

\section{Resident Representative}

The Fund's office in Bangui was closed in September 2003. 


\section{APPENDiX III: CENTRAL AFRICAN REPUbliC: Relations With THE WORLD BANK GROUP}

$(\text { As of November 20, 2006) })^{8}$

1. World Bank assistance to the Central African Republic (C.A.R.) has been disrupted by the recurrent conflicts during much of the past decade. The C.A.R. has been under suspension of IDA disbursements since January 2002, with protracted arrears of approximately US\$62.09 million as of November 20, 2006. The presidential and parliamentary elections in March and May 2005 marked the end of a two-year political transition, following a coup d'état in March 2003, and were generally deemed to have been satisfactorily conducted. The Bank's objective over the last year and a half has been to help the C.A.R. design and implement a framework to guide the country's recovery and longerterm development and poverty reduction efforts, and pave the way for a coordinated settlement of external arrears by multilateral creditors and increased volumes of donor financing. This is now well advanced, and scheduled to come to fruition at the end of November 2006.

\section{The Bank Group strategy in lending and non-lending activities}

2. Currently, there is one approved operation in the portfolio in support of HIV/AIDS prevention and control. The Bank approved a US\$17 million credit in December 2001, to support combating the spread of HIV/AIDS in a country where the prevalence rate is estimated at 10.5 percent. $^{9}$ An exception on suspension of disbursements was made for the project preparation facility (PPF) of the HIV/AIDS project. To date, three PPFs totaling US\$1.35 million have been fully disbursed. The Bank has approved a fourth PPF advance (US\$650,000) and the effectiveness date for the IDA credit has again been extended. Implementation of the PPFs has continued satisfactorily.

3. A Country Re-Engagement Note was presented to the Board in July 2004. It was centered on two building-blocks: (i) supporting a smooth transition by addressing urgent governance and security issues; and (ii) improving delivery of social services. The first building-block focuses on economic management, demobilization and reintegration of excombatants, and providing support for leadership capacity-building. The second buildingblock focuses on assistance in the education and health sectors, activities on HIV/AIDS. Activities in these areas during the transition were supported through a grant of US\$4 million from the LICUS Trust Fund.

4. The above LICUS Trust Fund allocation has already been fully committed and implementation is well advanced. In the case of the Social sectors, all activities are completed and an independent evaluation has assessed them as responsive to the emergency needs of CAR in the areas of education and health especially, despite the fact that financial resources involved were very limited. A second LICUS grant was approved on October 10,

\footnotetext{
${ }^{8}$ This document was approved by the Regional Operations Committee on November 27, 2006.

${ }^{9}$ The 2005 UNDP Human Development Report.
} 
2006 in the amount of US\$6.77 million, which will deepen the activities already undertaken in the area of public finance management and governance (US\$2.77 million), finance an assessment of the mining sector (US\$450,000), enhance the delivery of social services to rural populations (US\$2.75 million), including through community driven development initiatives, provide interim support to the fight against HIV/AIDS US\$400,000 and finance analytical work in the area of human security (US\$400,000).

5. In addition to the LICUS Grant, the Bank is currently preparing an Interim Strategy Note (jointly with the African Development Bank), which sets forth IDA's strategy over the next 18 months, with a financial exceptional IDA allocation in the amount of US\$100 million, which will be used to (i) provide support, in the form of a Reengagement and Institution-Building Support Program (RIBSUP) for arrears clearance, debt service payments, and some direct support to budget expenditures (total envelope of US\$82 million); and (ii) to support investment projects (US\$18 million). It is expected that arrears will be cleared on November, 28, 2006, following which the DPO will be presented to the Board. This will be followed by the ISN in December, at which point the preliminary document of the HIPC initiative will also be presented to the IDA Board.

\section{IMF-World Bank collaboration in specific areas}

6. The World Bank has worked closely with the IMF on the reform program in the C.A.R., and generally share the same views on policy issues. There is broad agreement on the core reform program in the C.A.R., namely: (i) reinforcement of public expenditure and public payroll management; (ii) revenue mobilization and improvement of tax and custom administration; (iii) improving governance and transparency; and (iv) improving the delivery of public services, including education and health.

Table 1: Bank-Fund Collaboration

\begin{tabular}{|l|l|}
\hline Area & Lead Institution \\
\hline 1. Fiscal area & \\
\hline Public expenditure management & IMF/World Bank \\
\hline Tax administration & IMF \\
\hline 2. Governance & \\
\hline Transparency efforts & IMF/ World Bank \\
\hline Natural resource management & World Bank \\
\hline 3. Other & \\
\hline Monetary and credit policy & IMF \\
\hline Social sector assessment & World Bank \\
\hline Poverty reduction strategy & World Bank \\
\hline External sector & IMF \\
\hline Debt sustainability analysis & IMF/World Bank \\
\hline
\end{tabular}


IDA actual and planned financial and non-financial support to CAR

Ongoing

- $\quad$ MDRP project: (US\$9.8 million, FY02, Funded by multi-donor trust fund and IDAadministered)

- Multi-Country HIV-AIDS Program: (US\$17 million, FY02, in spite of non-accrual status, disbursements were made through 4 project preparation facilities in an amount of US\$2 million, leaving an undisbursed balance of US\$15.0 million);

- $\quad$ LICUS I: (US\$4.0 million, FY05, Public finance management, Governance and social services delivery, support to PRSP preparation);

- $\quad$ LICUS II: US\$6.8 million, FY07, (Public finance management, governance, CDD projects, HIV/AIDS, and human security);

- $\quad$ Reengagement and Institution-Building Support Program, DPO (US\$82 million, FY07, Arrears clearance and budget support);

- $\quad$ Diagnostic Trade Integration Study, (Analytical and advisory activities, AAA, FY07);

- Country Financial Accountability Assessment, (AAA, FY07);

- $\quad$ Country Procurement Issues Paper, (AAA, FY07);

- $\quad$ Poverty Report, (AAA, FY07)

Planned

- $\quad$ Project support for infrastructure rehabilitation, FY07 (Amount to be determined to the extent that activities are funded from the US\$18 million remaining of exceptional IDA allocation or from the US\$17.5 million undisbursed balance from the Multi-Country HIV-AIDS Program);

- Regional Transport Facilitation Program, FY07 (Contribution to CAR component to be determined and to be funded from the remaining US\$18 million of exceptional IDA allocation);

- $\quad$ Project support for social services, FY07 (Amount to be determined to the extent that such activities are funded from the remaining US\$18 million of exceptional IDA allocation or from the US\$17.5 million undisbursed balance of the Multi-Country HIVAIDS Program);

- $\quad$ Public Expenditure Review, (AAA, FY08/FY09);

- $\quad$ Rural Sector Strategy, (AAA, FY08);

- $\quad$ Education Country Status Report, (ESW, FY07)

\section{Areas in which the World Bank leads and there is no direct IMF involvement}

7. The Government has advanced in its preparation of the (full) PRSP, with assistance from UNDP. The Bank is working closely with the UNDP and the Government on the PRSP 
process, and has scaled up its support to ensure that the PRSP will provide the requisite medium-term framework with sufficient depth and breadth of coverage of the country's recovery and longer term development and poverty reduction needs. The Bank has also added support to ensure that the PRSP document would include a monitoring and evaluation mechanism, as well as a comprehensive participation of major stakeholders. The full PRSP is expected to be completed at the end of the first semester of 2007. In the meantime, the Government has prepared (August 06) an Economic and Social Policy Framework (ESPF), supported by Government Matrix of Priority actions.

8. To assist demobilization and socio-economic reintegration of ex-combatants into their home communities, the Bank approved the Reintegration of Ex-combatants and Support to Communities Special Project in an amount of US\$9.8 million in April 2004. The project is funded entirely through the Multi-Donor Trust Fund (MDTF) of the Multi-Country Demobilization and Reintegration Program (MDRP), and is expected to contribute to the overall stability of the country by (i) demobilizing ex-combatants and reintegrating them socially and economically back into their community; (ii) strengthening the capacity of communities of return to ensure the sustainable reintegration of the ex-combatants; and (iii) supporting projects on security and conflict prevention in communities that are most affected by security problems. Project implementation was slowed by the election process, but supervision has been stepped up to ensure concrete results in the field.

9. To support the emergency rehabilitation of at least 80 communities in four prefectures (Kemo, Ouaka, Kemo, Basse Kotto and Mbomou), the Bank has signed a Grant agreement with an international NGO and with the Government in an amount of US\$2.75 million. The project is funded entirely through the Licus TF and is expected to establish a model for a community-driven approach that helps build social capital, provide critical social services, and restart some level of economic activity in the selected communities.

\section{Areas in which the World Bank leads and its analysis serves as input into the IMF- supported programs}

10 The Bank is taking the lead on laying the groundwork for the preparation of a medium term structural reform framework in the context of the PRSP. In addition to the LICUS Trust Fund activities, the Bank has continued to engage in analytical and advisory work. In collaboration with other partners, it has prepared a set of Policy Notes, focusing on key thematic areas including security, natural resource management, social sectors and public finance. A draft of the Policy Notes has been shared with the authorities, and provides an assessment of the current situation with a view of designing a framework for the country's recovery and longer-term development. The IMF has a strong interest in the financial sector from a macroeconomic perspective, including growth and the monitoring of quasi-fiscal deficits and contingent public liabilities, as well as an interest in governance and transparency issues in natural resources management.

11. During 2006, the Bank has also prepared a report on public procurement (CPIP), on trade (DTIS) and on public finance management (CFAA). In the latter area, reports were 
prepared on cash management and accounting nomenclature on civil service reform and payroll control. In the context of the LICUS II grant, and the Reengagement and InstitutionsBuilding Support Program, the Bank funded and is supporting governance-enhancing activities in the sectors of mining, forestry and telecommunications and in the judicial area. The objective pursued is to create an environment conducive to private sector development and to ensure the respect of investors' rights.

\section{Areas of shared responsibility}

12. The Bank and the IMF are working together to assess debt sustainability and HIPC eligibility for the C.A.R. The Bank and the IMF are also active in the area of regional integration. The Bank has been implementing a Regional Assistance Strategy for the CEMAC countries, including a support to the payments systems, while the IMF has been active in regional macroeconomic surveillance.

\section{Areas in which the Fund leads and its analysis serves as input into the World Bank- supported programs}

13. The IMF has taken the lead on core macroeconomic and fiscal policies, on revenue mobilization and the management of aggregate expenditures. The Bank has been working with the IMF to ensure consistency between its own projects and policy advice and the overall fiscal framework. In the framework of a donor partnership, the Bank has provided training and technical assistance to strengthen the C.A.R. public finance administration.

\section{Areas in which the IMF leads and there is no direct World Bank involvement}

14. The IMF has been leading the dialogue on monetary policy, exchange rate management, and balance of payments issues, although given the nature of the CFA franc arrangement, there is little scope for policy action in these areas at the national level.

Questions may be addressed to Brendan Horton (202-473-5587) or Ali Khadr (202-458-7860). 


\section{APPENdix IV: Central African RePublic: Statistical IsSUeS}

1. The statistical database is adequate for surveillance purposes but it suffers from weaknesses due to years of neglect, inadequate resources, and various conflicts. On the basis of a 1999 multisector statistical mission, efforts were initiated to improve the national statistical system including through adopting the statistics law and setting up a National Statistical Board in 2001. The authorities also decided to participate in the General Data Dissemination System (GDDS). The conflicts of 2002 and 2003 prevented these efforts from bearing fruit, and the statistical production and dissemination deteriorated further.

2. Efforts were renewed more recently to revive statistical improvement plans. With the support of a statistics expert mission during January 26-February 13, 2004, the Central African Republic (C.A.R.) became a participant in the GDDS. Its metadata were first posted on the IMF's Dissemination Standards Bulletin Board (DSBB) on June 14, 2004 and only recently updated for financial sector statistics. Issues of source data, compilation, and dissemination affect all sectors, but are particularly severe in the areas of the real sector, government finance, and external trade statistics.

\section{Real sector}

3. The compilation of national accounts is the responsibility of the Division of Statistics and Economic Studies (DSEE) of the Ministry of the Economy, Finance, Planning, and International Cooperation. The 1999 STA multisector mission found serious deficiencies in the institutional arrangements for compiling statistics as well as weaknesses in data collection procedures and compilation techniques. The authorities should continue efforts to improve the quality of national accounts estimates and the reporting of quarterly foreign trade data. At the same time, revisions are needed for the wholesale and the consumer price indices as the limited coverage and the obsolescence of the weights used in compiling these indices cast serious doubts on their accuracy.

4. A statistical expert visited Bangui during July 11-22, 2005 and found a serious resource gap at the DSEE and recommended a number of measures, particularly the redeployment of resources to strengthen the national accounts services. There is an urgent need to develop source data, by conducting surveys, particularly for the subsistence agriculture sector which represents an estimated 30 percent of the economy. In addition, estimates of activity in the informal sector are still based on a 1982 survey. In the manufacturing sector, estimation is based on an outdated list of enterprises and likely overestimates activity, given that many of these enterprises either do not exist or have reduced their production considerably. There is the pressing need to update the business register through a survey of enterprises and to reinstate publication of the industrial production index.

\section{Government finance}

5. The 1999 multisector statistics mission noted that there was no single primary data source that could be used for the production of government finance statistics and that the 
available information was not communicated to the Ministry of Finance. In February 2004, a government finance statistics mission underscored that, in order to establish a systematic compilation of government finance statistics, substantial additional assistance will be required, notably in the area of Treasury accounting and expenditure management, with a view to producing reliable source data and improving the accuracy of the measures of domestic arrears. The mission made specific recommendations toward this objective, and a subsequent March 2004 FAD mission confirmed and reinforced these recommendations. Support in this area is provided by an FAD public expenditure management advisor currently stationed in the Central African Republic. The GFS mission that visited Bangui during June 19-July 7, 2005 reviewed recent developments and proposed an action plan for improving the government financial operations table (Tableau des Opérations Financières de l'État, TOFE) and the Treasury cash plan.

\section{Monetary accounts}

6. Monthly data for the C.A.R., as well as for the other members of the Central African Economic and Monetary Community (CEMAC), are regularly reported to the Fund in electronic form by the Bank of Central African States (BEAC). Accuracy of data on currency in circulation is affected by large cross-border movements of currency among CEMAC member countries. Only 30 percent of banknotes issued in the C.A.R. by the BEAC National Directorate remain in the territory, 49 percent circulate in Cameroon and about 16 percent in Chad, while currency in circulation in the C.A.R. includes some 6 percent of banknotes from Republic of Congo, 6 percent of banknotes from Cameroon, and 4 percent of banknotes from Gabon.

7. The monetary and financial statistics (MFS) mission that visited Bangui in October 2006 assisted the authorities in assessing consistency between government finance statistics (bank financing) and monetary statistics (net position of the government). The mission also provided guidance in migrating to the new Standardized Report Forms for the submission of monetary statistics to STA, and helped update the metadata for the financial sector posted on the IMF website within the framework of the GDDS. However, the BEAC has yet to submit, for any of its member countries, monetary test data using the new SRF forms. Key recommendations from MFS mission included: (i) expansion of monetary statistics to the largest microfinance institution in the country (Crédit mutuel de Centrafrique);

(ii) finalization and implementation of the updated sectorized list of public entities to improve accuracy of monetary statistics and consistency with GFS; and (iii) verification of reliability of source data reported by commercial banks through the new electronic reporting system.

\section{Balance of payments}

8. As in other CEMAC countries, the agency responsible for the compilation of balance of payments statistics is the Balance of Payments Unit of the national agency of the BEAC. Past delays with data compilation and dissemination, which were mainly related to the transition from the fourth to the fifth edition of the Balance of Payments Manual, have been addressed through the recent implementation of methodological improvements. The last complete reporting, prepared by the national balance of payments committee, covered 2002 
annual data. Preliminary statements for 2003-05 are available from the national direction of the BEAC office in Bangui, and have been transmitted to the African Department. However, no data are transmitted to the Statistics Department, with balance of payments data published in the International Financial Statistics Yearbook only through 1994.

9. The October 1999 STA multisector mission provided a thorough assessment of needs in balance of payments statistics. Efforts have been made to address some of the problems identified by the mission, including training, compilation system, and development of a flexible questionnaire. Nonetheless, problems remain and the main issues concern data sources, including the need to update the BOP survey (list of respondents, reporting forms, and codification). Various methodologies or statistical techniques need to be reviewed, such as the computation of freight and insurance and procedures for attributing banknote movements among transactions. The timeliness of the biannual balance of payments (presently 90 days) needs to be improved.

\section{External and domestic debt}

10. External and domestic debt statistics are compiled by the Debt Directorate of the Ministry of Finance and Budget. The quality of data needs to be significantly improved and efforts are underway to verify with creditors the stock of external debt outstanding and of external arrears. To date, most of the multilateral debt data and at least 74 percent of the bilateral and commercial debt data have been reconciled. Hence, more than 90 percent of the total debt data have been reconciled. Similarly, domestic debt data are of poor quality, due in part to the difficulty of monitoring public expenditure on a commitment basis. However, the actual stock of government domestic arrears has been verified by a working group, with the help of a World Bank consultant. An external audit of this verification is planned to be completed by mid-2007. The Debt Directorate is currently seeking funding and technical expertise to upgrade their outdated debt data management software. 


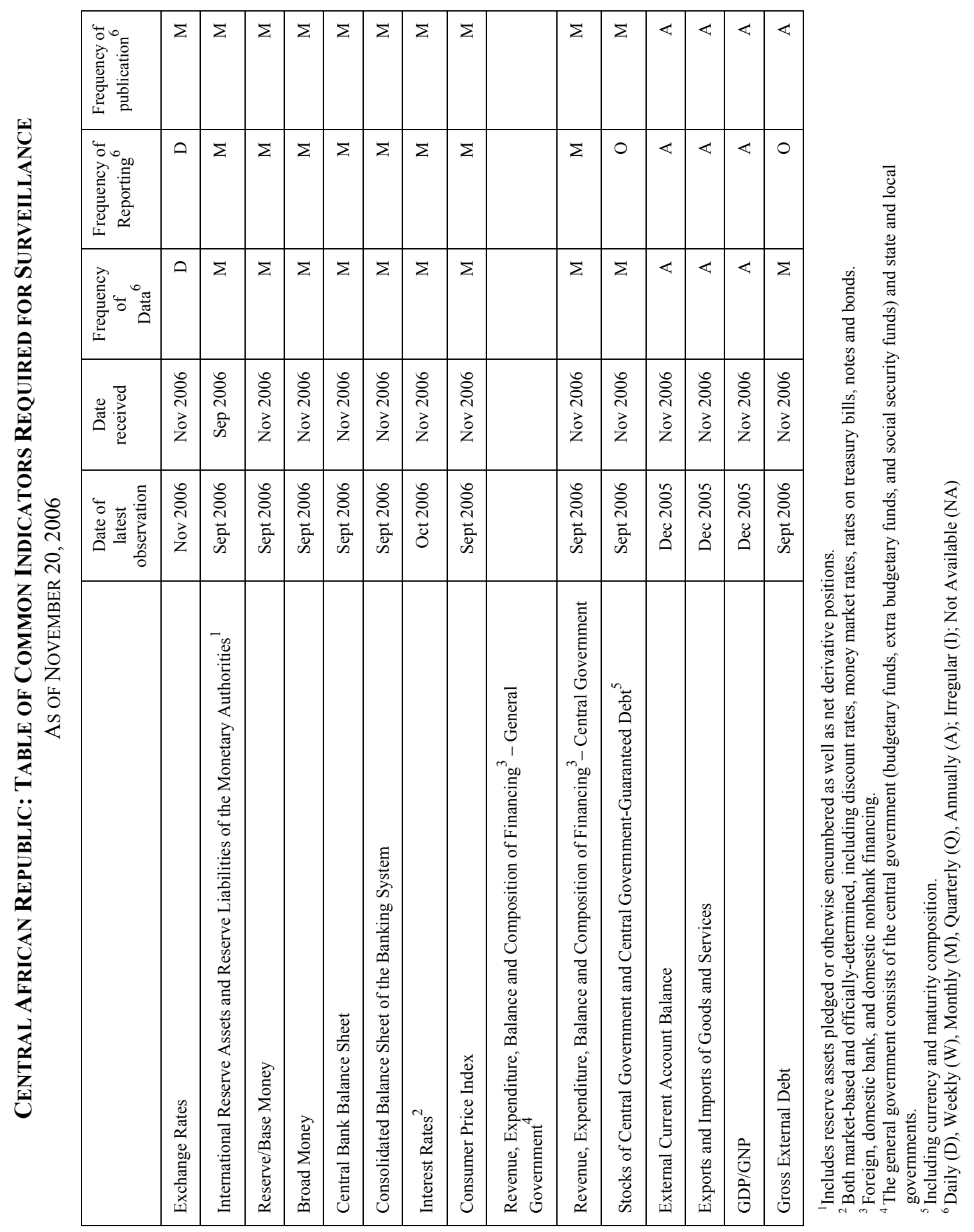




\section{Statement by the IMF Staff Representative December 22, 2006}

The following supplementary information has become available since the issuance of the staff report. This information does not alter the thrust of the staff's assessment in the abovementioned document.

- The prior action contained in the authorities' Letter of Intent requesting a new-threeyear Poverty Reduction and Growth Facility arrangement (Appendix I, Attachment I, Table 2) has been observed. This prior action concerned the issuance of an international competitive tender to undertake an external audit for the validation of domestic payments arrears that accrued during the period 1998-2004. The tender was opened on November 23, 2006. The external audit is expected to be concluded by end-June 2007.

- $\quad$ The staff has been informed by the staff of the African Development Bank that financing assurances sufficient to clear the Central African Republic's arrears to that institution have been secured. A board discussion to approve the clearance of these arrears is scheduled for December 20, 2006. 
Press Release No. 06/299

International Monetary Fund

FOR IMMEDIATE RELEASE

Washington, D.C. 20431 USA

December 22, 2006

\section{IMF Executive Board Approves US\$54.5 Million PRGF Arrangement for the Central African Republic}

The Executive Board of the International Monetary Fund (IMF) has approved a three-year arrangement under the Poverty Reduction and Growth Facility (PRGF) for the Central African Republic in an amount equivalent to SDR 36.2 million (about US\$54.5 million) to support the government's economic program into 2009. The first disbursement will be in an amount equivalent to SDR 17.6 million (about US\$26.5 million).

Following the Executive Board's discussion of the Central African Republic's IMF-supported economic program, Mr. John Lipsky, First Deputy Managing Director and Acting Chair, stated:

"The Central African Republic has made good progress in improving economic management under the Emergency Post-Conflict Assistance program. As a result of this progress, as well as improvements in the country's political and social situation, the economic recovery is gaining in strength. Given previous expenditure slippages, the recent strengthening in the fiscal position is especially noteworthy. The country has also made advances in structural reform in such areas as public financial management, tax and customs administration, and governance and transparency.

“The authorities' medium-term economic and financial reform program, supported by the PRGF arrangement, will help them to build a firm foundation for accelerating growth and alleviating poverty. The program aims to gradually eliminate the overhang of domestic debt and open room to support priority public spending and investment, increase credit to the private sector, and make external debt sustainable by regularizing relations with external creditors and benefiting from debt relief.

"The fiscal policy goal for 2007 is to increase the domestic primary surplus that emerged this year so that the government can stay current on domestic debt service and start repaying domestic debt. Reform of tax and customs administration will be vital to raising domestic revenue, and better management of the public finances will tighten expenditure control and prevent slippages.

"The authorities are determined to take the measures necessary to remove other obstacles to growth and poverty reduction. Enhancing financial intermediation will support the revival of the private sector, and trade and investment liberalization will help diversify and expand the export 
base. Given the importance of the natural resource sector, the authorities' intention to establish clear regulations for mining and forestry is well advised.

"The medium-term economic framework is consistent with the priorities emerging in the draft of the Poverty Reduction Strategy Paper, which is to be completed in mid-2007. The authorities are carefully elaborating detailed policies and priorities that can be supported by technical and financial assistance from the country's development partners.

"The regularization of relations with external creditors and debt relief under the enhanced Heavily Indebted Poor Countries Initiative (HIPC) and the Multilateral Debt Relief Initiative will help the Central African Republic regain external debt sustainability. In this regard, it is critical that the authorities promptly implement the macroeconomic and structural reform policies supported by the PRGF arrangement; strong performance under the program will help to bring the country to the HIPC decision point in the near future," Mr. Lipsky said.

The PRGF is the IMF's concessional facility for low-income countries. It is intended that PRGFsupported programs are based on country-owned poverty reduction strategies adopted in a participatory process involving civil society and development partners and articulated in a Poverty Reduction Strategy Paper (PRSP). This is intended to ensure that PRGF-supported programs are consistent with a comprehensive framework for macroeconomic, structural, and social policies to foster growth and reduce poverty. PRGF loans carry an annual interest rate of 0.5 percent and are repayable over 10 years with a 5 1/2-year grace period on principal payments. 


\section{Statement by Laurean W. Rutayisire, Executive Director for Central African Republic December 22, 2006}

\section{Introduction}

On behalf of my Central African authorities, we thank the Executive Board, Management and staff for their continued support to the Central African Republic. This assistance and constructive policy dialogue, including through technical assistance have laid the ground for an effective re-engagement of the international community and the consolidation of peace and national security. Notwithstanding the progresses made, my authorities are cognizant of the enormous challenges ahead, including the threat of the spillover of regional conflicts, insufficiency of human capacity and physical infrastructure, and a narrow export base which makes it vulnerable to external shocks.

Since 2003 when the present leadership came to office, the Central African Republic made significant progress in governance and economic reforms with limited external aid. My authorities accomplishments includes a successful transition towards a fully democratic system of government, with presidential and parliamentary elections widely recognized by observers as fair and transparent; restored macroeconomic stability; an end to decades-old trend of economic decline and a return to a positive rate of growth; and a reduction in inflation to the single digits. My authorities implemented a vigorous reform agenda, satisfactorily completing a staff monitored program, two Emergency Post-Conflict Assistance programs and more recently, the prior action to the request for the program supported by the PRGF.

\section{Recent Developments}

Preliminary data indicates that economic activity has been buoyant. A real GDP growth rate of $3 \frac{1}{2}$ is expected this year, with a surge in exports as the main engine of growth. Inflation has been generally subdued at 5 percent. On account of lower official transfers and an appreciation of the real exchange rate, the current account deficit is expected to widen to 3.3 percent of GDP.

My authorities made significant gains in the fiscal position this year, with the domestic primary balance projected to move from a deficit of $3 \frac{1}{2}$ percent of GDP in 2005 to a primary surplus of about $1 / 2$ percent of GDP in 2006. This strong performance is due to measures implemented by the authorities to raise revenue and improve tax administration.

My authorities fulfilled their commitment not to accumulated new arrears. Although with some minor delays due to administrative problems, no new wage arrears have been accumulated. Instead, payments equivalent to 0.5 percent of GDP have been made on domestic arrears, including salaries and pensions from 2005.

My authorities have implemented all the structural benchmarks of the EPCA program, including the publication on the internet of information related to fiscal developments, real sector, and corruption cases. Moreover, the State Legal Agent and the financial unit in charge of prosecuting financial corruption in the Ministry of Justice have started their work. 


\section{Medium Term Objectives and Policies for the 2007}

The medium term policy framework rests on the PRSP, which is in the process of being finalized in close consultation with stakeholders. Major pillars of the PRSP are:

1) Achieve annual real GDP growth of 4 to 5 percent through 2009, which would allow some modest progress toward meeting the income MDG.

2) Reduce annual inflation rate to 3 percent, in line with the long-term inflation trend in the CEMAC zone, so as to preserve external competitiveness.

3) Pursue fiscal consolidation to eliminate the overhang of domestic debt and free resources for growth-enhancing and poverty-reducing social policies.

4) Encourage private sector development, through fiscal consolidation and financial sector reforms that would increase the availability of credit to the private sector; trade liberalization; a restructuring of state-owned enterprises; and enhanced governance in the natural resource sector, including more reliable private property rights and contract enforcement.

5) Regularizing the country's relations with external creditors.

\section{Fiscal Policy}

Fiscal policy will be the main conduit to achieve the C.A.R authorities' medium term objectives, especially as monetary policy is conducted at the regional level. In 2007, my authorities are considering a combination of spending cuts and revenue performance improvements, in order to create the fiscal space required to fund priority sectors. The 2007 budget targets a domestic primary surplus of 1 percent of GDP.

On the revenue side, my authorities expect the reforms in tax and custom administrations to yield an additional 1 percent of GDP in tax collections, compared with 2006. After taking into account various sources of revenues, including from development partners, they anticipate an increase in total revenue from about 13 percent of GDP in 2006, to 15 percent next year.

Significant expenditure reductions are also planned. Among them, a cap on the wage bill will be in place, thus reducing the wage bill by $1 / 2$ percent of GDP next year. Non priority spending such as foreign travels and administrative costs will be compressed while efforts to identify ghost works and unqualified employers are expected to yield substantial payroll savings. However, the cap on the wage bill will not imply a reduction in the staffing of priority sectors such as health and education. In the context of the reform of the civil service which is now being considered, the needs of these sectors will be given due consideration. My authorities are also determined to reform the structure of the petroleum product pricing, in order to better help vulnerable household, while avoiding the need for budget subsidies. They have requested technical assistance from the Fund for this purpose. 
This fiscal rationalization will allow an increase in priority spending, such as capital expenditures, which are expected to rise by $1 \frac{1}{2}$ of GDP in 2007, the reform of the cotton sector, which is critical for alleviating poverty in rural areas, the reduction of the domestic debt equivalent to $2 \frac{1}{2}$ percent of GDP, and the timely payment of external payment obligations.

\section{Public Financial Management}

Weaknesses in public financial management in the past have fueled bad governance practices and made the country vulnerable to social and political instability. In a marked break from the past, my authorities are implementing vigorously tax and customs administration reforms. With Fund's technical assistance, my authorities plan to implement the following reforms in 2007: (i) update the list of taxpayers (including public enterprises) and ensure the list covers all applicable taxes; (ii) reduce the rate of non-compliance of large enterprises through the effective implementation of disciplinary actions against delinquent taxpayers and further intensification of audits; (iii) apply the ceiling of CFAF 30 million turnover for the purpose of taxation of all businesses (individual and companies) without any exception and allow enterprises subject to the flat tax to opt for the application of the regular tax regime; (iv) refrain from granting any new tax exemptions; and (v) apply all the available mechanisms for recovering tax arrears. By end-December 2007, my authorities are resolved to reduce the stock of tax arrears by at least CFAF 1 billion, net of uncollectible amounts.

\section{Monetary Policy and Financial Sector Policies}

Monetary and exchange rate policy in C.A.R are conducted by the regional central Bank, the Bank of Central African States (BEAC). The regional framework has been a helpful anchor to inflation expectations and an important source of short term financing in the past. Given the high cost of this source of funds, my authorities will seek alternative venues during the program period.

A weak banking sector and a low level of financial intermediation impose severe constrains on an efficient functioning of the C.A.R's economy. Accordingly, my authorities will seek, through a national strategy to promote financial development reforms, to facilitate access to credit and remove obstacles to financial intermediation. They take note of the findings of the recent Financial Sector Stability Assessment (FSSA) of the CEMAC. In the line of the report conclusions, my authorities intend to pursue in 2007:

- Legal reforms, in order to make credit collection activities more efficient, including the adoption by end-December 2007 of commercial laws and civil procedures related to debt collection and bankruptcy;

- The promotion of land surveys and modernization of the functioning of land and commercial registries, to facilitate the use of collateral for credit access;

- The implementation of anti-money laundering/combating the financing of terrorism laws (AML/CFT), 
In close coordination with the COBAC, my authorities will adopt measures that would enhance the stability in the financial sector, in particular, initiating the process of reconciliation and validation of potential liabilities of state owned enterprises toward commercial banks with a view to establishing options for their repayments. They will also pursue the timely recapitalization of the troubled commercial bank without contributing government resources, by recognizing the state-owned enterprises' non-performing loans in order to remove the uncertainty which prevents prospective investors from making offers.

\section{Structural Reforms}

In close consultation with the World Bank, my authorities are determined to improve the management of the natural resources sector. In the mining sector, efforts to upgrade the legal, regulatory and institutional settings, such as standardizing concession agreements, transparency over bonus payments, and full reporting of revenues from the sector in the Treasury, will be pursued. The Central African Republic is already participating in the Kimberly process and is taking steps to join the Extractive Industry Transparency Initiative (E.I.T.I).

Security and political stability are crucial prerequisites for making sustainable progress in all other areas. The disarmament program with the assistance of the UNDP has been intensified. So far, 96 percent of identified ex-combatants have been disarmed and demobilized. The program is now focusing on their successful reinsertion in civilian endeavors. Nevertheless, long lasting peace and stability will depend on the resolution of regional conflicts and my Central African Republic authorities count on the support of the international community.

\section{External Debt}

The debt situation of C.A.R. is unsustainable. My authorities give the normalization of their relations with creditors the highest priority. External payments arrears to the World Bank have been cleared as well as those to the African Development Bank. Measures have been taken to ensure that no new accumulation of arrears will occur and that the country will remain current with its obligations to the Fund. My authorities have approached the Paris Club and other bilateral and commercial creditors in a good faith effort to find a sustainable debt strategy.

Looking forward, my authorities are making efforts, with the assistance of the African Development Bank to improve their debt management capabilities. They will also pursue grant financing and will restrict foreign borrowing to loans on concessional terms.

\section{Conclusion}

In spite of a difficult post-conflict situation, my authorities have maintained a satisfactory track record of program implementation under the SMP and two successive EPCAs. Progresses in governance by conducting democratic elections and in joining the EITI initiative have been made. 
I'd like to reiterate my authorities' commitment to the highest standards of economic management going forward, and call on Executive Directors to favorably consider the request of my authorities for a new program supported by the PRGF facility which would pave the way to benefiting from enhanced HIPC debt relief and MDRI. Such a relief would enable my authorities to redirect resources towards poverty reduction and efforts to attain the Millennium Development Goals. 